$31(1) \mid 2002$

Varia

\title{
Integración y desarrollo de la región fronteriza peruano ecuatoriana: entre el discurso y la realidad, una visión local
}

Intégration et développement de la région frontalière péruano-équatorienne: entre le discours et la réalité, une vision locale Integration and development of the peru-ecuador border region: between discourse and reality, a local view

\section{Anne Marie Hocquenghem y Étienne Durt}

\section{OpenEdition}

Journals

Edición electrónica

URL: https://journals.openedition.org/bifea/6926

DOI: $10.4000 /$ bifea.6926

ISSN: 2076-5827

Editor

Institut Français d'Études Andines

Edición impresa

Fecha de publicación: 1 abril 2002

Paginación: 39-99

ISSN: 0303-7495

Referencia electrónica

Anne Marie Hocquenghem y Étienne Durt, «Integración y desarrollo de la región fronteriza peruano ecuatoriana: entre el discurso y la realidad, una visión local», Bulletin de l'Institut français d'études andines [En línea], 31 (1) | 2002, Publicado el 08 abril 2002, consultado el 21 septiembre 2021. URL: http://journals.openedition.org/bifea/6926 ; DOl: https://doi.org/10.4000/bifea.6926

\section{cc)}

Les contenus du Bulletin de l'Institut français d'études andines sont mis à disposition selon les termes de la licence Creative Commons Attribution - Pas d'Utilisation Commerciale - Pas de Modification 4.0 International. 


\title{
INTEGRACIÓN Y DESARROLLO DE LA REGIÓN FRONTERIZA PERUANO ECUATORIANA: ENTRE EL DISCURSO Y LA REALIDAD, UNA VISIÓN LOCAL
}

\author{
Anne Marie HOCQUENGHEM, Étienne DURT*
}

\section{Resumen}

En la primera parte de este artículo analizaremos los textos de los acuerdos de paz firmados entre Perú y Ecuador en 1998, para indicar de qué manera estos documentos tienden, reconociendo la frontera, a volverla permeable para que no constituya un obstáculo al actual proceso de globalización. En la segunda parte, con una perspectiva histórica de unos treinta y cinco años, indicaremos las fracturas, diferencias y complementariedades, naturales y sociales, que rinden cuenta de una complejidad regional que desconocen estos documentos. En la tercera parte describiremos la situación que se puede observar en los tres nuevos pasos fronterizos, prestando atención al medio ambiente, a la producción, a las vías de comunicación y a los intercambios, con la intención de evidenciar, a la escala local, los impactos del Plan Binacional de Desarrollo de la Región Fronteriza. Finalmente en la cuarta parte, en base a unas entrevistas con alcaldes y sus administrados, trataremos de comparar el discurso oficial con la realidad que se percibe y vive localmente, con el fin de formular algunas preguntas en cuanto a los problemas y a las posibilidades de integración y desarrollo de la región fronteriza.

Palabras claves: Perú, Ecuador, acuerdos de paz, frontera, integración, desarrollo, territorio y globalización.

\section{INTÉGRATION ET DÉVELOPPEMENT DE LA RÉGION FRONTALIÈRE PÉRUANO-ÉQUATORIENNE: ENTRE LE DISCOURS ET LA RÉALITÉ, UNE VISION LOCALE}

\section{Résumé}

Dans la première partie de cet article nous analyserons les textes des accords de paix, signés entre le Pérou et l'Équateur en 1998, pour indiquer comment ces documents tendent, en reconnaissant la frontière, à la rendre perméable pour qu'elle ne constitue pas un obstacle à l'actuel processus de globalisation. Dans la seconde partie, dans une perspective historique de quelques trente cinq ans, nous indiquerons les fractures, les différences et les complémentarités, naturelles et sociales, qui rendent compte d'une complexité régionale que ces documents ne reconnaissent pas. Dans la troisième partie nous décrirons la situation qui peut être observée aux trois nouveaux passages frontaliers, en prêtant attention à l'environnement, à la production, aux

"IRD UR 021 “Territorios y mundialización en los países del Sur” - CNRS-IFEA: casilla 181217, Lima 18, Perú. E-mail: amhocquenghem@ifeanet.org; durt@chavin.rcp.net.pe 
voies de communication et aux échanges, dans le but de mettre en évidence, à l'échelle locale, les impacts du Plan Binational de Développement de la Région Frontalière. Finalement dans la quatrième partie, sur la base d'entrevues avec des maires et leurs administrés, nous essayerons de comparer le discours officiel avec la réalité qui se perçoit et se vit localement, à fin de formuler quelques questions en rapport avec les problèmes et les possibilités d'intégration et de développement régional.

Mots clés : Pérou, Équateur, accords de paix, frontière, intégration, développement, territoire et globalisation.

\title{
INTEGRATION AND DEVELOPMENT OF THE PERU-ECUADOR BORDER REGION: BETWEEN DISCOURSE AND REALITY, A LOCAL VIEW
}

\begin{abstract}
In the first part of this article, we will analyze the texts of the peace agreement signed by Peru and Ecuador in 1998 to show how these documents, while they recognize the border, tend to make it crossable in order to remove an obstacle to the current process of globalization. In the second part, in an historical overview covering the last thirty-five years, we will underline fractures, differences and complementarities, natural and social, testifying to a regional complexity that the official documents do not recognize. In the third part, we will describe the situation that can be observed at the three new border's crossings looking at environment, production, ways of communication and exchanges, with the aim to show, at local scale, the impacts of the Binational Development Plan of the Border Region. Finally, in the fourth part, on the basis of interviews with mayors and their electors, we will try to compare the official discourse with the reality that is felt and lived locally, in order to ask some questions about problems and posibilities of integration and regional development.
\end{abstract}

Key words: Peru, Ecuador, peace agreements, border, integration, development, territory and globalization.

\section{EL TEMA DE INVESTIGACIÓN}

\section{1. Los acuerdos de paz de 1998}

La frontera entre Ecuador y Perú es una frontera administrativa que nace en la época colonial, cuando en el virreinato del Perú se crea la audiencia de Quito, y se transforma en frontera política-estatal durante la época republicana, objeto de numerosas disputas entre la Gran Colombia y el Perú y luego de conflictos armados entre este país y el Ecuador (Deler, 1981; 1982; 1995; Mercado Jarrín, 1981; Hocquenghem, 1991; 1998; Ulloa, 1997; Yepes, 1996; 1998; Cuvi, 1999; Bonilla, 1999). Después del conflicto de 1941, el Protocolo de Río de Janeiro de 1942 garantizado por Estados Unidos, Brasil, Argentina y Chile, impone un trazado fronterizo que es rechazado por el gobierno ecuatoriano del presidente José María Velasco Ibarra, a raíz de las dificultades de demarcación en la cordillera del Cóndor y en la zona LagartocochaGüeppí. El cuestionamiento del acuerdo firmado por ambas partes conduce a recurrentes incidentes fronterizos y a dos conflictos armados, ocurridos en 1981 y 1995. Es de 
recalcar que, a pesar de estos conflictos, la frontera nunca obstaculizó seriamente la circulación de ideas, personas y productos, ya sea por pasos de frontera oficiales o tradicionales. Aunque después del conflicto de 1941 los intercambios se dificultaron y luego del enfrentamiento de 1995 la inseguridad de la población fronteriza aumentó. Con la Declaración de Paz de Itamaraty, el 17 de febrero de 1995, se inicia el proceso que lleva a la firma, en Brasilia, el 26 de octubre de 1998, de los acuerdos de paz entre los gobiernos de los presidentes Jamil Mahuad Witt y Alberto Fujimori. El 13 de mayo 1999 se coloca el último hito fronterizo.

En la presentación de los documentos suscritos en Brasilia, publicados en Lima por el Ministerio de Relaciones Exteriores (1998), se indica que los acuerdos de paz constituyen, en esencia, una redefinición de la naturaleza y del signo de las relaciones entre las dos repúblicas. Se ha conseguido finalizar una prolongada historia de conflictos, diferencias y desconfianzas y los dos países fronterizos enfrentados militarmente se convierten en socios que encaran juntos, mediante la cooperación y la integración fronteriza, retos comunes de orden social y económico. La frontera delimitada y demarcada deja de ser fuente de conflicto y de separación para convertirse más bien en espacio de encuentro, de trabajo conjunto y de esfuerzo compartido entre pueblos que, además de tener innumerables vínculos históricos, son conscientes de la necesidad de afirmar permanentemente la paz y promover su desarrollo. Para garantizar la paz y el entendimiento entre el Perú y el Ecuador así como para contribuir a la atención de las graves limitaciones que agobian aún a sus pueblos, particularmente aquellos de la extensa región fronteriza, se firmaron en Brasilia, además del Acta Presidencial, varios documentos. Los primeros mencionados siendo el Tratado de Comercio y Navegación, luego el Acuerdo Amplio de Integración Fronteriza, Desarrollo y Vecindad y el Convenio de Aceleración y Profundización del Libre Comercio.

El Tratado de Comercio y Navegación de conformidad con el artículo VI del Protocolo de Río de Janeiro establece los derechos de los cuales gozará el Ecuador para la navegación pacífica y el comercio en el Amazonas y sus afluentes septentrionales. El Acuerdo Amplio de Integración Fronteriza, Desarrollo y Vecindad, según el discurso oficial, sobrepasa ampliamente la simple integración formal localizada y apunta a convertir la paz en múltiples posibilidades de desarrollo no sólo fronterizo, sino para el conjunto de los dos países. En su marco se tiene previsto liberar el tránsito de personas, vehículos, embarcaciones y aeronaves, y habilitar nuevos pasos fronterizos, como corresponde a dos países que han superado sus resquemores y suspicacias fronterizas. Dentro de este acuerdo el Plan Binacional de Desarrollo de la Región Fronteriza, además de impulsar la integración y la cooperación real entre los dos países, ha considerado la ejecución de programas y proyectos de infraestructura social y productiva así como la promoción de la inversión privada. Concurrentemente, el Convenio de Aceleración y Profundización del Libre Comercio contempla la liberalización casi total del intercambio para el año 2001. Se afirma que los documentos suscritos en Brasilia significan el fin de la tensión y el enfrentamiento entre los dos países y la apertura de un proceso novedoso y sugerente de cooperación e integración que tiende a consolidar la amistad y promover el mutuo beneficio. 
Al leer la publicación oficial de los textos de acuerdos de paz entre Perú y Ecuador surgen algunas preguntas, ¿cuál es el "proceso novedoso y sugerente" al cual dan paso en 1998?, ¿cuál es la "Integración” y el "Desarrollo" que pretenden lograr y con qué fin? y ¿a qué "Región Fronteriza" se refieren?

\section{2. El proceso de mundialización y su último avatar, la globalización}

Constatando que se trata de "Comercio" o más precisamente de "Aceleración y Profundización del Libre Comercio", intuimos que los acuerdos de paz forman parte de las condiciones necesarias para que se extienda el proceso de mundialización según los esquemas neoliberales y que el "proceso novedoso al cual dan paso" no es otro que el conocido proceso de globalización. De frente, a partir de lecturas entrecruzadas de diversos ensayos sobre el tema, algunas definiciones de los términos "Mundialización" y "Globalización" han tratando de aclarar los sentidos en los cuales los entendemos.

Del lado de la historia, Le Goff (2001) sugiere que el proceso de mundialización no es otro que el proceso histórico visto desde el único punto de vista de lo económico. Cita a Fernand Braudel, otro historiador, que piensa también que la historia económica del mundo es toda la historia del mundo considerada desde un solo observatorio, el observatorio económico. Pero, elegir este observatorio es privilegiar de antemano una forma de explicación unilateral y peligrosa porque no se pueden desligar los órdenes de lo económico, lo social, lo cultural y lo político.

Del lado de la geografía, Dollfus (1997a) define la mundialización como el intercambio generalizado entre las diferentes partes del planeta, el espacio mundial siendo el espacio de transacción de la humanidad. Resulta del conjunto de los procesos que permiten esta transacción generalizada entre los componentes de la humanidad. Es un hecho total, causado y causante, procediendo y funcionando por interacciones extremadamente complejas que requiere ser analizado como un entretejido de sistemas. Entiende la globalización como el último avatar de la mundialización. Un avatar marcado por la instantaneidad de la información, una autonomía de la esfera financiera frente a la economía que sin embargo controla, la multinacionalización de las grandes empresas, la ideología neoliberal como base de las políticas económicas. Un avatar que trastorna y reorienta los sentidos y valores de los sitios, de los territorios, de los límites, según como se ubican en cambiantes redes de relaciones, más funcionales, pero desigualmente repartidas. Este investigador piensa que la globalización, como sistema mundial neoliberal, durará un tiempo y que será tarea de las generaciones venideras la de reconstruir otro sistema mundial.

Del lado de la sociología, Bourdieu (2001: 25-31,93-108) precisa que la palabra globalización puede referirse a la unificación del campo económico mundial o a la extensión de este campo a la escala mundial. Pero significa algo totalmente diferente cuando se le da un sentido normativo, designando una política económica que tiende a unificar el campo de lo económico por medio de un conjunto de medidas jurídicopolíticas destinadas a destruir todo lo que se opone a esta unificación, todos los obstáculos, en mayoría relacionados con el Estado-Nación, que se oponen a esta extensión. La globalización económica es, entonces, el producto de una política puesta 
en marcha por un conjunto de actores e instituciones y el resultado de la aplicación de reglas deliberadamente creadas con fines específicos, la liberalización del comercio. $\mathrm{O}$, dicho de otra forma, el mercado mundial es una creación política, producto de una política más o menos concertada que tiene como efecto, y quizás como fin, al menos para los más lucidos y cínicos de los defensores del neoliberalismo, la creación de las condiciones de la dominación. De hecho la globalización confronta brutalmente actores y empresas que antes, cuando se trataba de procesos de modernización estaban encerradas y protegidas en los límites nacionales, con la competencia de fuerzas productivas y modos de producción más eficientes y poderosos. Así en los países con economías emergentes la desaparición de las protecciones lleva a la ruina las empresas nacionales, la supresión de todos los obstáculos a la inversión extranjera las conduce a la quiebra y se venden a bajo precio a multinacionales. Bourdieu nota también que la globalización tiende al establecimiento de una igualdad formal que en el marco de una desigualdad real favorece a quienes establecen, por medio de las intervenciones falsamente neutras de las grandes instancias internacionales con sedes establecidas en los centros de poder, como la tríada de Washington o las Naciones Unidas y sus dependencias newyorkinas, las reglas del juego que permiten unificar para dominar mejor.

Otro sociólogo, Touraine (1997), percibe que el proceso de globalización a la vez que unifica, fragmenta. La cultura hoy no condiciona la organización social que, a su vez, no determina la actividad técnica y económica. Se produce una ruptura de las relaciones entre la esfera valorizada de la economía y la tecnología y la esfera despreciada de la cultura y la identidad, una separación entre el mundo instrumental y el mundo simbólico. Los elementos materiales globalizados, bienes de consumo, medios de comunicación, tecnologías o flujos financieros se desligan de una particular organización social. Constata que vivimos juntos en la medida en que hacemos los mismos gestos y utilizamos los mismos objetos, lo que no nos iguala, y que no logramos comunicar más allá del intercambio de signos de la globalización, lo que no nos uniformiza pero sí nos desubica. Esto lo lleva a formular una interrogante: ¿cómo podremos vivir juntos, iguales y diferentes, en una sociedad cada vez más dividida entre redes que nos instrumentalizan y comunidades que nos encierran y no nos dejan comunicar?

En función de estas definiciones y percepciones del proceso de mundialización y de su último avatar, vislumbramos que los documentos firmados en Brasilia entre el gobierno peruano y el gobierno ecuatoriano, con la venia de los gobiernos garantes del Protocolo de Río de Janeiro, dan de hecho paso al proceso de globalización. La integración buscada en el marco de este proceso no es otra que la integración al mercado mundial y el desarrollo en perspectiva, en el actual contexto capitalista, de las fuerzas productivas, con especial atención a lo material, dejando de lado lo social. Entendemos entonces que los acuerdos de paz forman parte de los actos de sumisión a una hegemónica política económica que intenta, imponiendo una ley del mercado mundial único, someter el planeta a un orden neoliberal, según una tradición histórica particular que se enraíza en la Europa del siglo XVI y florece actualmente en los Estados Unidos de América del Norte. 
En el marco de esta investigación nos importa considerar las consecuencias, positivas y negativas, de este proceso de globalización en el caso particular de la región fronteriza peruano-ecuatoriana y tratar de aportar, a partir de este caso especifico, algunos elementos de respuestas a la pregunta de Alain Touraine.

Pero nos queda una interrogante: ¿cómo se define la "Región Fronteriza” en los textos oficiales firmados en Brasilia?

\section{3. La región fronteriza}

La frontera peruano-ecuatoriana queda, después de la colocación del último hito en 1999, claramente delimitada y demarcada entre el hito de la Punta Capones en el litoral pacífico, pasando por el piedemonte Oeste del macizo andino, por sus cordilleras y su piedemonte Este, y atravesando la planicie amazónica hasta el hito de Boca Güeppi, en el confluente de este río con el río Putumayo. Lo que no se vislumbra claramente en los documentos oficiales firmados en Brasilia es la "región fronteriza" a la cual se alude utilizando diversas expresiones, "cordón fronterizo", "zona fronteriza", "áreas de frontera" o "regiones fronterizas", lo que indica que no se concibe como un territorio definido por sus límites. Y el simple hecho de no definir los límites de la región fronteriza demuestra que los acuerdos de paz se elaboraron y firmaron en el marco de la política neoliberal que tiende a considerar flujos y redes sin límites con el fin, reconociendo las fronteras nacionales y estableciendo las reglas de juego para cruzarlas, de extender espacios fronterizos globalizados.

En el marco de nuestra investigación nos interesa un espacio andino ubicado entre los paralelos $3^{\circ}$ y $6^{\circ}$ Sur y se extiende desde el litoral pacífico, $81^{\circ} 15^{\prime}$ Oeste, hasta la cuenca del Río Morona, $77^{\circ}$ Oeste. Abarca las provincias ecuatorianas de El Oro, Loja, Zamora-Chinchipe, parte de Morona-Santiago y los departamentos peruanos de Tumbes, Piura, junto con las provincias de San Ignacio y Jaén en el departamento de Cajamarca y la provincia de Condorcanqui en el departamento de Amazonas, (Fig. 1). Lo tomamos como objeto de estudio porque lo venimos trabajando desde medio siglo, en el marco de diferentes programas de instituciones francesas, el Centro Nacional de Investigación Científica, CNRS, el Instituto Francés de Estudios Andinos, IFEA, y el Instituto de Investigación para el Desarrollo, IRD, en colaboración con instituciones peruanas y ecuatorianas (Hocquenghem \& Lanning, 1996; Hocquenghem \& Lanning con la colaboración de Gondard, 1999).

Es un espacio de transición, entre los Andes septentrionales y centrales, con una extrema variedad de recursos naturales. En este espacio, sociedades históricamente relacionadas conformaron a lo largo del tiempo, durante la época prehispánica, colonial y republicana, por medio de sus diferentes organizaciones sociales y tecnologías, un territorio de una gran riqueza de recursos culturales específicos, diferentes de aquellos de los territorios que lo rodean. Esta diversidad es percibida por sus moradores quienes sienten y describen las fracturas del entorno natural y social que comparten, así como las diferencias y complementariedades que a la vez lo dividen y lo relacionan, tanto de cada lado de una y otra parte de la frontera. Esta población constituye una sociedad extremadamente fragmentada que afirma por lo tanto fuertes identidades locales que 
dificultan la emergencia de una conciencia de su identidad regional, si bien se percibe diferente de sus vecinas. Y como sabemos que sin sociedad conciente de su identidad regional no hay región, entendemos que la región fronteriza que enfocamos como objeto de estudio es por ahora una "no-región" (Hocquenghem, 1998).

Sin embargo, tomando en cuenta el hecho de que la sociedad fronteriza se percibe diferente de sus vecinas, se puede pensar que si lograría fortalecer su conciencia de una identidad regional propia y proyectarla a nivel nacional, internacional y global, podría constituirse una verdadera región fronteriza. Como "región posible", la proyectamos a futuro y nos interesa tratar de vislumbrar, entre el discurso oficial y la realidad local, el impacto de la globalización sobre su porvenir.

\section{4. Entre el discurso y la realidad, una visión local}

En la primera parte de este artículo presentaremos los textos de los acuerdos de paz publicados por el Ministerio de Relaciones Exteriores del Perú (1998). Prestando especial atención al Acuerdo Amplio de Integración Fronteriza, Desarrollo y Vecindad, en particular a su Título V el Plan Binacional de Desarrollo de la Región Fronteriza, (capítulos peruano y ecuatoriano), y a sus avances al 2001. Esto para indicar de qué manera los documentos oficiales y las puestas en marcha de los programas que proponen tienden, reconociendo la frontera, a volverla permeable para que no sea un obstáculo al libre comercio, a la integración al mercado mundial, igualando las condiciones de vida de parte y de otra de la frontera, unificando a escala regional y nacional para dominar mejor los dos países.

En la segunda parte, con una perspectiva histórica de unos treinta y cinco años, veremos a grandes rasgos, en base a estudios anteriores citados en la bibliografía, las fracturas, diferencias y complementariedades, naturales y sociales, transfronterizas así como internas en ambos lados de la frontera. Esto para indicar la especificidad de la complejidad de esta región, que los textos de los acuerdos de paz no toman en consideración.

En la tercera parte, pasaremos a describir la situación que se puede observar en los tres nuevos pasos fronterizos, oficialmente habilitados a raíz de la firma de los acuerdos de paz, prestando especial atención al medio ambiente, a la producción, a las vías de comunicación y a los intercambios. Esto con la intención de percibir, a escala local, los impactos del Plan binacional de Desarrollo de la Región Fronteriza, unos tres años después de la firma de los acuerdos de paz.

Finalmente, en la cuarta parte, resumiremos unas entrevistas a alcaldes y a sus administrados tratando de comparar el discurso oficial con la realidad que se percibe y vive localmente. Esto con el fin de formular algunas preguntas en cuanto a los problemas y las posibilidades de integración y desarrollo de una "no-región" fronteriza, y el fortalecimiento de una conciencia de identidad sin la cual la sociedad regional no logrará diseñar sus propias políticas de reproducción social.. 


\section{EL DISCURSO OFICIAL}

\section{1. Los acuerdos suscritos entre Perú y Ecuador}

La lectura de los documentos firmados en Brasilia (Ministerio de Relaciones Exteriores del Perú, 1998) deja entrever en que medida tienen como objetivo una integración binacional que apunta a una integración al mercado mundial y a un desarrollo material y no social. Son de hecho actas de sumisión al orden neoliberal que tiende a unificar para dominar mejor, a acelerar el proceso de globalización frenado, en esta parte del mundo, por los conflictos fronterizos entre Perú y Ecuador. Veamos estos documentos.

\section{1. 1. El Acta Presidencial de Brasilia}

Con este documento, suscrito por Alberto Fujimori y Jamil Mahuad Witt presidentes del Perú y del Ecuador, Carlos Saul Menem, Fernando Henrique Cardoso, Eduardo Frei Ruiz-Tagle, presidentes de Argentina, Brasil y Chile, Thomas F. McLarty III, representante personal del Presidente de los Estados Unidos de América, así como por Fernando de Trazegnies Granda y José Ayala Lasso, Ministros de Relaciones Exteriores del Perú y del Ecuador, culmina el proceso de conversaciones sustantivas previsto en la Declaración de Paz de Itamaraty del 17 de febrero de 1995. En Brasilia se da oficialmente término, en forma global y definitiva, a las discrepancias entre las dos repúblicas de manera que, sobre la base de sus raíces comunes, ambas Naciones se proyecten hacia un promisorio futuro de cooperación y mutuo beneficio (Ministerio de Relaciones Exteriores, 1998: 47-51). Conforme al Protocolo de Río de Janeiro de 1942 y al Laudo del Capitán Braz Dias de Aguiar, los firmantes:

"Declaran que con el punto de vista vinculante emitido por los Jefes de Estado de los Países Garantes, en su carta de fecha 23 de octubre de 1998 , ... quedan resueltas en forma definitiva las diferencias fronterizas entre los dos países. Con esta base dejan registrada la firme e indeclinable voluntad de sus respectivos Gobiernos de culminar, dentro del plazo más breve posible, la fijación en el terreno de la frontera terrestre común”.

La frontera es delimitada y demarcada el 13 de mayo de 1999.

\section{1. 2. El Tratado de Comercio y Navegación}

Este tratado no se relaciona directamente con la región fronteriza andina que nos interesa sino con la amazónica, regula la navegación fluvial y terrestre y crea dos "Centros de Comercio y Navegación", destinados al almacenaje, la transformación y la comercialización de mercancías en tránsito, procedentes de Ecuador o destinadas a su territorio (Ministerio de Relaciones Exteriores, 1998: 53-61).

Vale la pena notar que fue mal recibido, tanto por los ecuatorianos que reclamaban parte del territorio peruano, como por los peruanos que no veían por qué dejar las embarcaciones ecuatorianas surcar con los mismos derechos que las nacionales las aguas del Amazonas y sus afluentes septentrionales y, menos todavía, ceder en concesión por 50 
años dos terrenos de 150 hectáreas para que los ecuatorianos establezcan "Centros de Comercio y Navegación" en las cercanías de Saramiriza y Pebas.

De hecho, de una y otra parte de la frontera, la historia de los conflictos recientes no dejaba ver claramente que este tratado resultaba, ante todo, de una voluntad internacional, al servicio de una política neoliberal y de intereses globalizados, de eliminar las trabas al Acuerdo de Libre Comercio de las Américas, ALCA, para crear condiciones favorables a un libre tránsito en la Amazonía peruana desde la frontera con Ecuador hasta el río Amazonas.

Y no nos queda ninguna duda, la firma del Tratado de Comercio y Navegación, marca la separación entre un mundo instrumental, en el cual el Ecuador consigue su anhelado acceso al Amazonas, y un mundo simbólico, en el cual el Perú conserva su frontera, la ruptura de relaciones entre la esfera valorizada de la economía y la tecnología y la esfera despreciada de la cultura y la identidad, signos de la globalización según Alain Touraine.

\section{1. 3. El Acuerdo Amplio de Integración Fronteriza, Desarrollo y Vecindad}

En este documento el espíritu y las expresas redacciones sobrepasan la simple integración, formal y localizada, apuntan a convertir la paz en múltiples posibilidades de integración y desarrollo no sólo fronterizo, sino del conjunto de los dos países (Ministerio de Relaciones Exteriores, 1998: 63-159). Los gobiernos peruano y ecuatoriano firmaron este acuerdo:

"Recogiendo la aspiración de ambos pueblos de que sus relaciones se desarrollen de modo permanente en un clima de paz, concordia, entendimiento y cooperación que permita potenciar el rico y diverso caudal de tradición, historia y recursos que los une;

Seguros de que la nueva etapa de relación que se inicia entre los dos países ofrecerá promisorias perspectivas de progreso para los pueblos peruano y ecuatoriano, a través de la integración y de la cooperación que asegure la paz y el progreso de ambas naciones;

Persuadidos de que dicha cooperación facilitará el desarrollo económico y social, así como la integración de ambos pueblos, contribuyendo a mejorar su calidad de vida y las posibilidades de progreso de las generaciones futuras;

Teniendo en cuenta que las poblaciones fronterizas y sus autoridades y entidades representativas deben constituirse en actores principales de la integración y de la cooperación en las áreas de frontera, promoviendo el desarrollo y una fructífera relación de vecindad entre sus habitantes;

Conscientes de la necesidad de actualizar y perfeccionar los mecanismos existentes entre ambos países para promover la cooperación e integración bilateral y facilitar el tránsito y la circulación de personas, bienes y medios de transporte entre los dos países; 
Afirmando que la promoción, el respeto y la protección de los derechos de las personas constituye exigencia básica para que la integración fronteriza y la cooperación entre el Perú y el Ecuador satisfagan los intereses y las aspiraciones de los dos pueblos;

Convencidos de la importancia de armonizar políticas de desarrollo para el aprovechamiento sostenible de los ecosistemas en la frontera común, que hagan posible la preservación y protección de la biodiversidad y el aprovechamiento racional de los recursos compartidos; y decididos a apoyar el desarrollo sustentable de las comunidades nativas de la región fronteriza fortaleciendo su identidad cultural; ..."

Este acuerdo fue muy bien acogido de los dos lados de la frontera, al menos en la región andina que nos interesa, pero estamos frente a una comedia de las equivocaciones. De hecho el término "integración” se entendió según las expectativas de cada uno. Los fronterizos imaginaron una integración regional y algunos vieron una posibilidad de descentralización del poder en los dos países; otros, cercanos a este poder, proyectaron una integración binacional hacia una integración al mercado mundial. El título $\mathrm{V}$ de este acuerdo, el Plan Binacional de Desarrollo de la Región Fronteriza y su Financiamiento, fue considerado con cierto entusiasmo en una región fronteriza que tendía a abarcar todo el norte del Perú y el sur del Ecuador, donde el término "desarrollo" fue interpretado por todos y cada uno en la perspectiva de inversiones y, por lo tanto, oportunidades de ganancias en la zona fronteriza. Corrió la voz de una disponibilidad de 3 millones de dólares y en consecuencia se elaboraron a toda velocidad, tanto a escala local como regional, nacional y global, así como en todas las instituciones, públicas y privadas, proyectos de desarrollo fronterizo. Se organizaron y multiplicaron encuentros binacionales de toda índole y apareció un abanico de asociaciones de toda naturaleza constituidas en la perspectiva de futuras reparticiones de los fondos de la paz. Volveremos sobre los detalles de este acuerdo que nos interesa muy particularmente en el marco de nuestra investigación.

\section{1. 4. El Convenio de Aceleración y Profundización del Libre Comercio entre el Ecuador y el Perú}

Este convenio lo suscribieron los gobiernos peruano y ecuatoriano (Ministerio de Relaciones Exteriores, 1998: 161-166):

"Conscientes que la liberalización del comercio bilateral permitiría afianzar las relaciones entre Perú y Ecuador, en esta nueva etapa de profunda vinculación de los dos países;

Convencidos que un comercio libre significará la apertura de nuevas oportunidades para los agentes económicos, que impulsará el crecimiento económico de ambos países;

Seguros que la vinculación de los empresarios en los ámbitos del comercio y la inversión conducirá a aumentar el grado de confianza y cooperación recíprocas; 
Considerando que mediante Decisión 414 de la Comunidad Andina, se acordó el Programa de Liberación del Perú y los Países Miembros, para conformar la Zona de Libre Mercado hasta 2005;

Teniendo en cuenta lo establecido en el artículo 121 del Acuerdo de Cartagena;

Deciden acordar la aceleración y profundización del proceso de desgravación, según se establece en el presente Convenio."

Es difícil afirmar con más fuerza un acuerdo total con los esquemas neoliberales y el proceso de globalización. No vale la pena, por ahora, explayarse sobre cómo, según este convenio, se realizará la aceleración y profundización del proceso de desgravación arancelaria tendiente a incrementar las corrientes de comercio entre las partes, ni sobre las excepciones y otras nóminas, reglamentaciones o clasificaciones tomadas en cuenta en este documento.

\section{1. 5. El Acuerdo de Constitución de la Comisión Binacional Peruano- Ecuatoriana sobre Medidas de Confianza Mutua y de Seguridad}

Esta comisión ha sido constituida, según el discurso oficial, como marco institucional político militar que permitirá la acción conjunta, concertada y cooperativa tendiente a restaurar la confianza y a promover vías de encuentro y acercamiento entre ambas naciones respecto de cuestiones de carácter militar (Ministerio de Relaciones Exteriores, 1998: 167-175):

"Reafirmando la vocación de paz de ambos países;

Reafirmando su pleno respecto al Derecho Internacional y a los principios consagrados en la carta de las Naciones Unidas y en la Carta de la Organización de Estados Americanos; ..."

Esto entre gobiernos hoy reconocidos como corruptos, cuando en el Perú la dupla Fujimori-Montesinos violaba primero los derechos humanos y luego los constitucionales, con la aprobación de los gobiernos de los países garantes. Y no sorprende, el proceso de globalización tiende a extenderse en base al monopolio del ejercicio de un poder de las más nefastas y vergonzosas índoles.

2. 1. 6. El Acuerdo para la Fijación de Medidas para Asegurar el Funcionamiento Eficaz del Canal de Zarumilla

Esel Acuerdode bases y el reglamento para laadministración del Canal de Zarumilla y la utilización de sus Aguas (Ministerio de Relaciones Exteriores, 1998: 177-196).

2. 1. 7. El Acuerdo para la Navegación en los sectores de los Cortes de los ríos y en el río Napo, adoptado mediante Notas Canjeadas por los Gobiernos del Perú y del Ecuador

Son notas que se refieren a la navegación en la frontera amazónica (Ministerio de Relaciones Exteriores, 1998: 197-201). 
Volvamos ahora al documento que más nos interesa en el marco de nuestra investigación, El Acuerdo Amplio de Integración Fronteriza, Desarrollo y Vecindad. Leamos detenidamente cada uno de sus títulos, para tratar de entender en qué sentido quienes los escribieron y suscribieron entienden sus términos (Ministerio de Relaciones Exteriores, 1998: 63-159).

\section{2. El Acuerdo Amplio de Integración Fronteriza, Desarrollo y Vecindad}

\section{2. 1. Normas Generales}

El Título I de este acuerdo consta de 4 artículos y de 6 anexos y presenta el contenido de este importante documento.

\section{2. 2. La Comisión de Vecindad Peruano-Ecuatoriana}

El Título II consta de 5 artículos y del anexo I Reglamento de la Comisión de Vecindad Peruano-Ecuatoriana. Especifica que la Comisión de Vecindad da las orientaciones generales para la cooperación bilateral, la aplicación del régimen fronterizo y para la buena marcha del Plan Binacional de Desarrollo de la Región Fronteriza (Ministerio de Relaciones Exteriores, 1998: 66-67, 76-77). Según su reglamento:

“... es la instancia de nivel político y de carácter representativo encargada de impulsar, apoyar y coordinar en forma dinámica la cooperación e integración entre los dos países, prestando especial atención al desarrollo de las regiones fronterizas y a la complementación empresarial y productiva. Está conformada por representantes de alto nivel de los sectores público y privado del Perú y del Ecuador.

... identifica y promueve los proyectos e iniciativas que genere una comunidad de intereses, económica y socialmente significativos para ambos países, con particular énfasis en el mejoramiento de la infraestructura, de los servicios y del aprovechamiento de los recursos compartidos.

... está presidida por los Ministros de Relaciones Exteriores de los dos países. Su estructura no sustituye a institución nacional o mecanismo bilateral alguno, sino armoniza y agiliza la consecución de sus objetivos.

... considera todos los temas que tienen relación con el desarrollo económico y social armónico y mancomunado y que promueve la cooperación e integración de los dos países, con prioridad en las regiones fronterizas.

... alentará los vínculos de todos los sectores de la sociedad civil entre los dos países, incluyendo los intercambios comerciales y la inversión privada."

Esta comisión establece los "Comités Técnicos Binacionales". Inicialmente se constituyeron, en el orden siguiente, el Comité de Régimen Fronterizo, que se preocupa de facilitar los flujos transfronterizos, el de Facilitación del Comercio, que no necesita aclaración en lo que lo concierne, así como los de Educación, de Salud y de Pesquería. Estos Comités constituyen "Grupos de Trabajo Binacionales" compuestos de representantes de los sectores público y privado. 
Entendemos que esta comisión impulsa una integración binacional y en este marco presta una especial atención en el desarrollo de indefinidas regiones fronterizas. Su naturaleza es mixta, pública y privada y sus objetivos son en primer lugar económicos, con particular énfasis en el mejoramiento de estructuras materiales, y en segundo lugar sociales, pero sin lineamientos especiales. En el marco del proceso de globalización busca, vale la repetición, unificar los dos países según los esquemas neoliberales.

\section{2. 3. El Fortalecimiento de la Cooperación Bilateral}

El Título III consta de sólo dos artículos y busca actualizar, ampliar y fortalecer los acuerdos de cooperación bilateral vigentes y establecer nuevos convenios en otras áreas que se estimen prioritarias y de interés común. Se señalan algunas líneas de acción:

- Ampliar y fortalecer los convenios de cooperación científica y técnica en campos de relevancia para el desarrollo económico y social, tales el transporte, la irrigación, el turismo, la agricultura y agroindustria, la minería y la energía.

- Intensificar la colaboración en los esfuerzos de prevención de salud, campañas inmunológicas y de saneamiento ambiental, sea directamente, o con apoyo de la Organización Mundial de la Salud, la Organización Panamericana de la Salud, el Convenio Hipólito Unanue, la UNICEF y otros organismos.

- Aprovechar la infraestructura y los servicios educativos de ambos países en la zona de frontera y estimular los intercambios educativos en el ámbito escolar y universitario, así como promover el conocimiento mutuo de las diversas expresiones culturales.

- Coordinar las tareas de prevención de desastres, tales como los ocasionados por el Fenómeno El Niño, e intensificar el apoyo mutuo para contrarrestar sus efectos dañinos, particularmente en la zona de frontera, a través de las entidades nacionales de defensa civil y al amparo del Convenio sobre Desastres Naturales de 1997.

- Actualizar y fortalecer los acuerdos en materia de sanidad animal y vegetal, para mejorar el control sanitario en la zona de frontera y facilitar el intercambio comercial de productos agropecuarios.

- Impulsar la cooperación en el campo pesquero.

- Aunar esfuerzos en la prevención y represión de actos delictivos y coordinar la lucha contra las drogas.

- Aprovechar de manera coordinada recursos mineros en zona fronteriza.

- Expandir e interconectar y aprovechar de manera coordinada sus respectivos sistemas eléctricos a escala vecinal, regional y nacional.

- Establecer mecanismos y realizar esfuerzos conjuntos de cooperación para el desarrollo del turismo internacional, binacional y fronterizo.

- Desarrollar estudios y proyectos ambientalmente sostenibles para el mejoramiento de las condiciones de vida de las comunidades nativas, contando con la activa participación de sus pobladores.

Esta enumeración atestigua de poca reflexión en cuanto a la presentación, organización y priorización, de los temas por tratar. La cooperación entre las dos 
naciones no parece ser una meta primordial en esta primera etapa del proceso de integración binacional. Las perspectivas presentadas reflejan, una vez más, el dominio de los aspectos económicos, relacionados con infraestructuras de extracción, producción, protección de bienes materiales, así como de reglamentación de sus usos. Se trata de una cooperación binacional para normar, es decir unificar los dos países, otra vez vale la redundancia, para dominarlos mejor en el marco neoliberal que sustenta el actual proceso de globalización.

\section{2. 4. El Régimen Fronterizo}

El Título IV consta de seis artículos con el Anexo 2 - Convenio sobre Tránsito de Personas, Vehículos, Embarcaciones Marítimas y Fluviales y el Anexo 3 - Reglamento de los Comités de Frontera Peruano-Ecuatorianos. Se trata de volver la frontera delimitada y demarcada permeable con la creación de nuevos pasos fronterizos oficiales y con el establecimiento de normas en cuanto a quiénes, cómo, cuándo, para qué y con qué circularán. Se inicia con el:

"Artículo 12

Las Partes otorgarán prioridad a los programas y proyectos destinados a establecer y facilitar los servicios a los flujos turístico y comercial en la frontera común mediante la suscripción de un Convenio sobre el Tránsito de Personas, Vehículos, Embarcaciones Fluviales y Marítimas y Aeronaves, que consta como Anexo 2 del presente Acuerdo.

Artículo 13

Se establece los Comités de Frontera como mecanismos de coordinación binacional, subsidiarios del Comité Técnico Binacional de Régimen Fronterizo, encargado de supervisar y colaborar en la aplicación de los acuerdos en materia de régimen fronterizo. En el Anexo 3 del presente Acuerdo se incorpora el Reglamento de los Comités de Frontera."

Es de notar que, según el reglamento, el comité de frontera está presidido en forma alternada por autoridades nombradas por los gobiernos, el Prefecto departamental peruano y el Gobernador ecuatoriano de la provincia.

Artículo 14

"En adición a los pasos de frontera terrestre existentes en Aguas VerdesHuaquillas y en La Tina-Macará, las Partes convienen en habilitar nuevos pasos de frontera en Cariamanga-Ayabaca, Lalamor-Alamor y ZumbaNamballe, los que deberían entrar en funcionamiento en un plazo no mayor de 180 días.” Dejando constancia que “... las partes podrán establecer otros Pasos de Frontera... para fortalecer el comercio entre los dos países."

Obviamente los tratados están redactados desde un punto de vista y en un lenguaje administrativo. Se requiere para entenderlos consultar el Apéndice A del Anexo 2 que incluye las Definiciones utilizadas en el convenio entre Perú y Ecuador sobre tránsito de personas, vehículos, embarcaciones fluviales y marítimas y aeronaves (Ministerio de Relaciones Exteriores, 1998: 89-91). Un Paso de Frontera: 
"Es el lugar habilitado por las autoridades nacionales competentes para el ingreso y salida al territorio de la otra Parte, por vía terrestre y fluvial, de personas, vehículos, embarcaciones, animales y mercancías."

En un paso de frontera hay un CENAF, Centro Nacional de Atención en Frontera, otras veces llamados Centro de Atención en Frontera, lo que demuestra cierta falta de rigurosidad del texto (Ministerio de Relaciones Exteriores, 1998: 89,70). Es lo que se denominaba CENAF y hoy se llama CEBAF Centro Binacional de Atención en Frontera:

"Es el conjunto de instalaciones y oficinas ubicado en un solo lugar del paso de frontera construido específicamente para realizar las inspecciones, comprobaciones, trámites o diligencias indispensables para la salida de un país y el ingreso al otro por vía terrestre."

Y, si no hay CENAF, debe de haber un Puesto de Control Fronterizo que consiste en:

"Instalaciones ubicadas en el paso de frontera donde se cumplen las inspecciones, trámites o diligencias indispensables para la salida de un país y el ingreso al otro, en los lugares donde no se haya creado un Centro de Atención en Frontera -CENAF-."

Siguiendo con las definiciones administrativas se puede precisar que una Zona de Libre Tránsito:

"Es el territorio de ambas Partes ubicado a uno y otro lado de un paso de frontera y que se extiende desde el límite internacional hasta el lugar donde se localiza el CENAF o el puesto de control fronterizo, comprendiendo los centros poblados situados dentro de dicho ámbito."

Y el Tránsito Local de Personas:

"Es aquel que tiene lugar dentro de la Zona de Libre Tránsito y que requiere, como única condición, portar el documento de identidad nacional."

En cuanto al Tránsito Transfronterizo:

"Es el que tiene lugar por tierra, agua o aire desde cualquier punto del territorio de una Parte a cualquier punto dentro de la Región Fronteriza de la otra Parte."

Mientras que el Tránsito Binacional:

"Es el que se efectúa por tierra, agua o aire, desde cualquier punto del territorio de una Parte, a otro cualquiera de la otra Parte, excepto la Región Fronteriza."

Se menciona un Comprobante de Tránsito Transfronterizo:

"Es el formulario gratuito y simplificado, de formato común acordado por las Partes que contiene el nombre de la persona, su domicilio, número de documento de identidad y la fecha de ingreso al territorio de la otra Parte en régimen de tránsito transfronterizo, para efectos exclusivos de registro." 
Y se establece gratuitamente una Tarjeta Andina de Migración,TAM, que:

"Es el formulario que deberá llenar el pasajero, en tránsito binacional, para efectos exclusivos de registro."

Se debe tener muy en cuenta que, en este lenguaje administrativo, una Región Fronteriza:

"Es el territorio de las Partes habilitado para la circulación en régimen de tránsito transfronterizo, según cada modo de transporte establecido en este Convenio."

En el Anexo 2 , Título segundo, que trata del tránsito de personas, se encuentra, al final del artículo 13, una indicación en cuanto a lo que podría ser una delimitación de la zona fronteriza (Ministerio de Relaciones Exteriores, 1998: 81-82) :

"El Tránsito terrestre transfronterizo de personas normado en el presente

Título se aplicará inicialmente en las provincias ecuatorianas de El Oro,

Loja y Zamora-Chinchipe, y los departamentos peruanos de Tumbes, Piura y Cajamarca."

Y en el Anexo 3 que hace referencia a Comités de Frontera se mencionan a pares de circunscripciones, El Oro-Tumbes, Loja-Piura y Zamora-Chinchipe-Cajamarca.

Se podría suponer que si las provincias de Morona-Santiago, Pastaza, Orellana y Sucumbíos, y los departamentos de Amazonas y Loreto, no se incluyen en este artículo 13 es porque ningún paso oficial está por ahora habilitado a lo largo de cerca del $80 \%$ de la frontera que atraviesa territorios amplios y poco poblados. Lo cierto es que los textos oficiales no precisan lo que sería un territorio fronterizo.

El Régimen Fronterizo establece las reglas de juego que permiten permeabilizar la frontera y reglamentar el tránsito transfronterizo, de hecho ensanchar, según las perspectivas de una integración al libre mercado mundial, una indefinida zona fronteriza. Pasemos ahora a considerar como, en el marco del Acuerdo Amplio, se prevé el desarrollo de una región fronteriza que oficialmente no se concibe como un territorio delimitado sino como una red de intereses globalizados.

\section{2. 5. El Plan Binacional de Desarrollo de la Región Fronteriza y su Financiamiento}

El Título V consta de 17 artículos organizados en 4 capítulos, a los cuales se suman 6 anexos. Veamos cada uno de los capítulos con el objetivo de entender el propósito, la finalidad y la estructura, del Plan Binacional de Desarrollo de la Región Fronteriza y su Financiamiento (Ministerio de Relaciones Exteriores, 1998, Título V, Capítulo 1: 70-72):

- El Plan Binacional.

- El Fondo Binacional.

- El Grupo Consultivo de Financiamiento Internacional.

- El Grupo Binacional de Promoción de la Inversión Privada. 
El Plan Binacional

"Artículo 18

Con el propósito de elevar el nivel de vida de las poblaciones del norte y nororiente del Perú y del sur y oriente del Ecuador y a fin de impulsar la integración y la cooperación entre los dos países, las Partes acuerdan llevar adelante un Plan Binacional de Desarrollo de la Región Fronteriza, que tendrá una duración de diez años y que se ejecutará de conformidad con los lineamientos generales descritos en el presente título.

Artículo 19

Con la finalidad de ordenar la captación de recursos y promover la adecuada ejecución de sus programas y proyectos, el Plan Binacional de Desarrollo de la Región Fronteriza contará con la siguiente estructura funcional:

- Un Directorio Ejecutivo Binacional, que estará integrado por los Capítulos Peruanos y Ecuatorianos;

- Un Comité Asesor Internacional

La Estructura Organizativa del Plan se describe en el Anexo 4.

Artículo 20

El Plan Contempla los siguientes cuatro Programas:

- El Programa Binacional de Proyectos de Infraestructura Social y Productiva.

- Los Programas Nacionales Peruano y Ecuatoriano de Construcción y Mejoramiento de la Infraestructura Productiva en las Regiones Fronterizas.

- Los Programas Nacionales Peruano y Ecuatoriano de Construcción y Mejoramiento de la Infraestructura Social y de Aspectos Ambientales en las Regiones Fronterizas.

- El Programa de Promoción de la Inversión Privada.

El contenido de cada programa está descrito en el Anexo 6 de este Acuerdo."

Veremos más adelante lo que son estos programas y cómo se desarrollan hasta el 2001.

"En el desarrollo de los programas y proyectos incluidos en el Plan se deberá necesariamente considerar el impacto ambiental de las obras a ser ejecutadas. Además, cuando sea necesario, con la finalidad de lograr eficiencia en las inversiones y un adecuado ordenamiento territorial, se hará estudios de zonificación ecológica económica o se tomará en cuenta los estudios existentes."

Es de notar que, de manera general, el Plan Binacional toma muy en cuenta, siguiendo las directivas globalizadas, los impactos ambientales de sus diferentes programas:

"En adición a los proyectos derivados de los anexos mencionados en el presente artículo, las Partes podrán presentar, directamente o por intermedio de la Comisión de Vecindad, proyectos específicos a ser incluidos en el Plan Binacional." 


\section{“Artículo 22}

Los principales mecanismos financieros que serán utilizados para obtener los recursos necesarios para la ejecución del Plan Binacional de Desarrollo de la Región Fronteriza serán los siguientes:

- Aportes y gestiones directas de los Gobiernos del Perú y del Ecuador.

- Un Fondo Binacional para la Paz y el Desarrollo.

- Un Grupo Consultivo de Financiamiento Internacional Perú-Ecuador.

- Un Grupo Binacional de Promoción de la Inversión Privada.

- Otros."

El Capítulo 2 del Plan Binacional trata del Fondo Binacional para la Paz y el Desarrollo (Ministerio de Relaciones Exteriores, 1998: 72-73).

El Fondo Binacional para la Paz y el Desarrollo

"Artículo 25

A fin de promover y apoyar el financiamiento de los programas y proyectos pequeños y medianos previstos en el Plan Binacional de Desarrollo de la Región Fronteriza, las Partes convienen en crear un Fondo Binacional para la Paz y el Desarrollo Perú-Ecuador.

El Fondo se constituirá con aportes de recursos provenientes de los Gobiernos del Perú y del Ecuador, de los países amigos, de instituciones multilaterales, de organizaciones no gubernamentales y de otras organizaciones privadas.

El Fondo emitirá Certificados de Paz y Desarrollo por cada cinco millones de US \$ recibidos y podrá celebrar convenios para obtener aportes no reembolsables bajo otras modalidades de cooperación.

Artículo 26

El Fondo Binacional administrará sus recursos principalmente a través de cuatro ventanillas de acceso diseñadas para financiar directamente los proyectos pequeños y medianos incluidos en los programas básicos del Plan que figuran en el artículo 20 de este Acuerdo y los estudios y trabajos requeridos para la ejecución de los mismos, así como para apoyar la inversión privada de mayor cuantía.

Las ventanillas de acceso proporcionarán recursos para lo siguiente:

a) Para la ejecución de proyectos de participación ciudadana y de desarrollo comunitario.

b) Para la construcción y mejoramiento de la infraestructura social, productiva, ambiental y de servicios.

c) Para el financiamiento de la mediana, pequeña y micro empresa.

d) Para la preparación de proyectos y para la promoción de la inversión privada. 
Artículo 27

El Fondo Binacional para la Paz y el Desarrollo de la Región Fronteriza estará regido por la Estructura Organizativa establecida en el Anexo 6 de este Acuerdo, el mismo que podrá ser elevado a la categoría de Estatuto aprobado por las Partes. El Fondo tendrá una Asamblea, un Directorio y una Secretaría Ejecutiva."

El Grupo Consultivo de Financiamiento Internacional

"Artículo 28

A fin de apoyar el financiamiento de los proyectos de mayor envergadura previstos en el Plan Binacional de Desarrollo de la Región Fronteriza, las Partes convienen en promover, de manera conjunta, la organización y convocatoria a un Grupo Consultivo de Financiamiento Internacional.

Con este fin, las Partes buscarán el apoyo del Banco Mundial, el Banco Interamericano de Desarrollo, la Corporación Andina de Fomento, las agencias especializadas del sistema de Naciones Unidas, las agencias del sistema interamericano, los Gobiernos de los países amigos y otras fuentes de financiamiento internacional.

Artículo 29

La convocatoria al Grupo Consultivo de Financiamiento Internacional se hará cuando se disponga de los estudios necesarios para los programas y proyectos de mayor envergadura contemplados en el Plan Binacional de Desarrollo de la Región Fronteriza."

El Grupo Binacional de Promoción de la Inversión Privada

"Artículo 30

Se establece el Grupo Binacional de Promoción de la Inversión Privada Perú-Ecuador con el objeto de promover las inversiones de empresarios peruanos, ecuatorianos o de terceros países en proyectos binacionales o nacionales ubicados en las regiones fronterizas. El Grupo diseñará los mecanismos para estudiar las posibilidades de inversión existentes y difundirlas adecuadamente entre los inversionistas potenciales."

Los artículos referentes al Plan Binacional son claros. Pretenden elevar el nivel de vida de las poblaciones fronterizas a fin de impulsar la integración y la cooperación, no de la región fronteriza, sino de Perú y Ecuador. Para esto se crean instituciones supranacionales, se elaboran programas que tienden a mejorar infraestructuras productivas con miras a igualar condiciones materiales antes que sociales, y se movilizan fondos nacionales, internacionales y mundiales, públicos y privados. Y entendemos que estos fondos globalizados servirán para unificar los dos países, para dominarlos mejor. 


\section{2. 6. Artículos finales}

El Título VI se refiere a la solución de las controversias que puedan surgir de la aplicación de algún aspecto de este acuerdo o de los convenios suscritos en el marco del mismo, a la difusión de este documento. Especifica que entrará en vigor después de haber sido aprobado por las partes conforme a sus respectivos ordenamientos jurídicos, que será de duración ilimitada, pudiendo cualquiera de las Partes proceder a su denuncia en conjunto o en parte con un plazo no menor de seis meses de anticipación.

Con este marco general del Acuerdo Amplio veamos ahora su Anexo 5 donde se definen los cuatro programas del Plan Binacional de Desarrollo de la Región Fronteriza y sus objetivos (Ministerio de Relaciones Exteriores, 1998: 125-154). Al leerlos veremos que todos estos programas apuntan a inversiónes en infraestructuras materiales.

\section{3. Los programas del Plan Binacional}

\section{3. 1. El Programa Binacional de Proyectos de Infraestructura Social}

y Productiva, " $A$ "

Pretende contribuir al mejoramiento de la infraestructura productiva y social en aquellas zonas donde Perú y Ecuador comparten recursos o tienen economías complementarias, fortaleciendo el proceso de Integración Fronteriza.

En este programa se incluyen los costos de los grandes proyectos, como el de irrigación Puyango-Tumbes, el plan urbano del eje Tumbes-Machala, la interconexión vial, el manejo de cuencas hidrográficas, la reforestación, la evaluación de recursos naturales, los estudios hidromorfológicos para navegación y otros no precisados.

Es el rubro estimado más costoso, con un total de 1498 millones de US \$, de los cuales 1298 son fondos públicos y 200 son fondos privados, conjuntamente para las dos partes.

2. 3. 2. Los Programas Nacionales Peruano y Ecuatoriano de Construcción y Mejoramiento de la Infraestructura Productiva en las Regiones Fronterizas, " $B$ "

Pretenden contribuir al mejoramiento de la infraestructura productiva y de servicios en las regiones fronterizas de ambos países, con obras orientadas a brindar facilidades para el tránsito fronterizo, el desarrollo sostenible de zonas con potencialidad productiva y la construcción de infraestructura física que fomente la interacción local productiva y comercial.

Entran en este rubro el costo de la construcción de Centros Binacionales de Atención en Frontera, CEBAF, proyectos de desarrollo sostenible, proyectos de infraestructura física, es decir represas e irrigación, generación de electricidad, muelles, puertos y atracaderos, aeropuertos, terminales terrestres, caminos rurales y pequeños proyectos bajo licitación. El monto total estimado es de 400 millones de US \$, 200 millones para cada país. 


\section{3. 3. Los Programas Nacionales Peruano y Ecuatoriano de Construcción y Mejoramiento de la Infraestructura Social y de Aspectos Ambientales en las Regiones Fronterizas, " $C$ "}

Buscan contribuir al mejoramiento de la infraestructura social y cultural en las regiones fronterizas de ambos países, vía la preparación de programas o el desarrollo de obras en salud, educación, saneamiento y desarrollo urbano, servicios básicos y medio ambiente. Bajo este rubro entra el costo de los proyectos de salud, educación, agua potable y alcantarillado, desarrollo urbano, electrificación, telecomunicaciones, pequeños proyectos bajo licitación y, conjuntamente, lo que se refiere a Comunidades Nativas, medio ambiente y reforestación. El monto total estimado es de 500 millones de US \$, 250 millones para cada país.

\section{3. 4. El Programa de Promoción de la Inversión Privada, "D"}

Los objetivos de este programa apuntan a la identificación de las áreas y oportunidades de inversión en las cuales el sector privado pueda participar en el financiamiento y ejecución de proyectos, definiendo el marco legal que lo haga factible. Entran en este rubro el costo de interconexión de oleoductos, interconexión eléctrica, establecimiento de circuitos de turismo, exploración y explotación minera, interconexión de telecomunicaciones, establecimiento de una red bancaria fronteriza, concesiones en infraestructura, correo fronterizo, pesca artesanal, industrial, acuicultura y otros. Para este rubro se estima un total de 602 millones de US \$, de los cuales 2 millones son fondos públicos y 600 millones son fondos privados.

Estos programas, otra vez, se orientan al mejoramiento de infraestructuras materiales. Ahora bien, a casi tres años de la firma de los acuerdos de paz, el Plan Binacional tiene una estructura funcional compuesta por un Directorio Ejecutivo Binacional, un Comité Asesor Internacional, un Directorio del Fondo Binacional para la Paz y el Desarrollo y un Comité Coordinador Binacional. Veamos cuales son sus avances, según los textos oficiales (Capítulos peruano y ecuatoriano 2001).

\section{4. Los avances del Plan Binacional}

\section{4. 1. El Directorio Ejecutivo}

Este directorio integrado por los Capítulos Ecuatorianos y Peruanos se constituyó el 12 de agosto de 1999 en Saramiriza, en el departamento peruano de Loreto. Es conforme al artículo 19 del Acuerdo Amplio, con una estructura organizativa prevista en el anexo 4. El Directorio Ejecutivo se reunió cinco veces, aprobando su reglamento, fijando las normas para el Comité Coordinador Binacional y sus respectivas sedes en Quito y Lima. Su presidencia es rotativa, la ejerció en 1999 Perú y en 2000 Ecuador. Con el fin de fortalecer la institucionalidad del Plan Binacional se obtuvo cooperaciones técnicas del Programa de las Naciones Unidas para el Desarrollo, PNUD, del Banco Interamericano de Desarrollo, BID, y de la Corporación Andina de Fomento, CAF. El Plan Binacional comprende el período 2000-2009 y requiere un aproximado de 3000 millones de US \$ para financiar sus cuatro programas. Durante el primer año, el 
directorio dedicó la mayor parte de su esfuerzo a captar recursos. Por lo que cuenta con cuatro mecanismos principales:

- Aportes de los gobiernos de Ecuador y Perú.

- Cooperación No Reembolsable.

- Créditos concesionales.

- Inversión Privada.

El Plan Binacional aspira a captar, a lo largo de su período de vida, unos 600 millones de US $\$$, en créditos de cooperación, recursos no reembolsables, de los cuales aproximadamente 160 han sido comprometidos por el Grupo Consultivo.

En cuanto a créditos concesionales, recursos reembolsables, el directorio ha efectuado una serie de gestiones tendientes a poner en marcha dicho mecanismo, que deberá cubrir los principales proyectos de infraestructura productiva, social y ambiental. La meta trazada es de 1600 a 1800 millones de US \$. Y corresponde a cada país asumir los créditos ofrecidos por los organismos financieros multinacionales. A fines del 2000 , dichos ofrecimientos suman 1230 millones. La CAF ha otorgado dos créditos al Perú y al Ecuador y se tramitan créditos con el BID y BM.

En enero 2000 la CAF acordó al Perú un crédito por 8 millones, comprometiéndo el Gobierno peruano a colocar una contrapartida de 4 millones de US \$, suma que será utilizada para los estudios de factibilidad del Plan Urbano Tumbes-Machala así como del aeropuerto de Iquitos y los estudios de factibilidad y definitivos de los ejes viales 2 , Arenillas-Sullana, 4, Loja-Saramiriza, y 5, Mendez-Saramiriza, los puentes internacionales de los ejes 1, Guayaquil-Piura, 2, 3 Loja-Sullana y 4, vías complementarias, Plan Integral de los ejes 1, 2, 3 y 4 y centros binacionales de atención en la frontera.

En octubre 2000 la CAF acordó al Ecuador un crédito de 25 millones de US \$, con una contraparte nacional de 7,5 millones de US \$ suma que servirá para programas de infraestructura fronteriza, entre otros el Proyecto Tahuin y demás proyectos de irrigación, instalaciones de microcentrales hidroeléctricas, sistemas de agua potable y alcantarillado, caminos rurales, el Eje vial 5, aeropuertos y aeródromos, reforestación y manejo de recursos naturales comunes en la región fronteriza, comunidades indígenas, medio ambiente y reforestación.

Finalmente, en cuanto a recursos de la inversión privada el Plan Binacional aspira atraer entre 600 y 800 millones de US \$, con el fin de sentar bases sólidas para que el proceso de desarrollo fronterizo sea sostenible más allá de su duración. Se está avanzando en el diseño de una estrategia general para promover esta inversión.

\section{4. 2. El Comité Asesor Internacional}

Este comité está formado por aquellos países y organismos que han otorgado contribuciones significativas al Fondo Binacional y tiene como función acompañar el desarrollo del Plan Binacional, haciendo las recomendaciones pertinentes para su buena marcha. Sobre la base del interés expresado durante la reunión del Grupo Consultivo y a lo recomendado por el Directorio del Fondo Binacional, se invitaron a 
seis países, Alemania, Brasil, España, Estados Unidos, Italia y Japón, y a tres organismos multilaterales, BID, CAF, PNUD, a formar parte de este comité que se instaló el 30 de octubre de 2000 en la sede del BID en Washington.

\section{4. 3. El Directorio del Fondo Binacional}

Se constituyó este directorio el 12 de agosto de 1999, en Saramiriza. Se reunió seis veces designando a su primer Secretario Ejecutivo, aprobando su reglamento, elevado a condición de Estatuto. Decidió que parte de los recursos de constitución del Fondo Binacional, cubrirían los gastos administrativos para el funcionamiento del Comité Coordinador Binacional.

Durante el primer año de funcionamiento, este directorio ha empleado sus esfuerzos en la captación de recursos no reembolsables. Ha suscrito dos convenios con la CAF para que brinde servicios de Tesorería y Auditoria. Sobre la base del primero de estos convenios, los gobiernos de Ecuador y Perú han realizado sus aportes iniciales al Fondo, por 10 y 5 millones de US \$ respectivamente. En el caso peruano fueron aportes en dólares, en el caso ecuatoriano en bonos del Estado. Si el gobierno ecuatoriano abonó dos veces más que el Perú es en consideración a las necesidades básicas de los 68 cantones fronterizos, estimando indispensable incorporar un mayor número de proyectos de carácter prioritario, así como los recursos para prevención, por un monto de 5 millones de US \$ adicionales. Estos fondos se distribuyen a través de las cuatro ventanillas del Fondo Binacional y se canalizan por medio de Entidades Ejecutoras. Para ello, se fijaron criterios específicos de calificación y a partir de enero del 2000 se procedió a la selección de las referidas entidades, con las cuales se negociaron sendos convenios.

\section{4. 4. El Comité Coordinador Binacional}

Integrado por los Directores Ejecutivos de los respectivos Capítulos Nacionales del Plan Binacional y por el Secretario Ejecutivo del Fondo Binacional. Este comité tiene una oficina en Quito y otra en Lima. Dichas oficinas cuentan con un reducido equipo técnico que apoya en el proceso de captación de nuevos recursos, su canalización hacia la región fronteriza, así como el seguimiento y la evaluación de los proyectos.

\section{4. 5. Distribución de los recursos del Fondo Binacional}

En el transcurso del año 2000 se depositaron 14 millones de US \$ en la CAF en su calidad de Tesorero del Fondo Binacional, el Perú aportando primero 4 millones, con el compromiso de añadir el 1 millón faltante. Este capital ha sido distribuido de manera diferente en Ecuador y Perú.

Ecuador ha invertido sus 10 millones de US \$ a través de la sola ventanilla de "Financiamiento de proyectos de infraestructura social, productiva, ambiental y de servicios". En convenio con las municipalidades, se realizaron numerosas obras de saneamiento ambiental, sistema de agua potable, de alcantarillado sanitario y pluvial, relleno sanitario, tratamiento de desechos sólidos, laguna de oxidación, pavimentación 
y adoquinado de vías urbanas, mercado. Es evidente que los alcaldes utilizaron los recursos de esta ventanilla para realizar obras de infraestructura básica de utilidad pública y leyendo el informe sobre los avances del Plan Binacional queda claro dónde y que son cada una de estas obras (Plan Binacional de Desarrollo de la Región Fronteriza, Ecuador-Perú a diciembre del 2000, Capítulo Ecuatoriano).

Perú en cambio ventiló su contribución entre las cuatro ventanillas, si bien la ventanilla "Promoción de la micro, pequeña y mediana empresa" no se habilitó a diciembre del 2000, se prevé que recibirá el millón de US \$ que falta abonar.

Por la ventanilla "Preparación de proyectos para la promoción de la inversión privada y estudios especiales" se atribuyeron 622000 US \$, a los cuales se sumaron los recursos de las cooperaciones técnicas ascendientes a un monto de 63072 US \$, de los cuales sólo 86264 se invirtieron en los siguientes estudios:

- Desarrollo de la institucionalidad del Plan y el Fondo binacional.

- Marco conceptual para el desarrollo de la región fronteriza.

- Indicadores sociodemográficos y económicos de esta región.

- Fortalecimiento de capacidades locales para el desarrollo.

- Perfil del proyecto para el desarrollo humano de la cuenca binacional de Zamora-Santiago.

- Análisis situacional y prioridades de acción sugeridas para la provincia de Condorcanqui, Amazonas.

- Estrategia y diseño del programa de promoción de la inversión privada.

- Memorial de la cultura y la biodiversidad amazónica.

- Propuesta de funcionamiento y operadores para el programa de medianas, pequeñas y microempresas, PyMEs.

- Identificación de posibles operadores del programa de PyMEs.

- Estrategia de participación de la sociedad fronteriza en el proceso de integración.

Por la ventanilla de "Financiamiento de proyectos de infraestructura social, productiva, ambiental y de servicios" se atribuyeron 2 millones de US \$ a los CTARs, planteando contrapartidas que en conjunto ascendieron a 996969 US \$, casi un millón, recursos con los cuales se aprobó la ejecución de 95 proyectos. El CTAR-Tumbes, con 12 proyectos aprobados, recibe 241280 US \$, el CTAR-Piura con 21 proyectos recibe 909481 US \$, el CTAR-Cajamarca, con 24 proyectos recibe 730391 US \$, el CTARAmazonas con 17 proyectos, recibe 570430 US \$ y el CTAR-Loreto, fuera de nuestro ámbito de estudio, con 21 proyectos recibe 645115 US \$. A fines del año 2000 los CTARs habrían gastado un tercio del presupuesto en obras de instalación ante todo de redes de energía eléctrica, antenas y paneles, algunas redes de agua potable, construcciones de aulas escolares y puestos de salud.

Por la ventanilla "Proyectos de participación ciudadana y desarrollo comunitario" se atribuyeron 1047000 US \$ del Fondo Binacional, más una dotación de 797000 US \$, de la US-AID, de la Fundación Friedrich-Ebert, de la Agencia Canadiense para el Desarrollo, de la Embajada de Francia en Ecuador y de fondos locales. Tumbes recibió 
unos 174000 US \$, Piura 374000 US \$, Cajamarca 346000 US \$ y Loreto 283000 US \$. Los cuadros no son tan fáciles de comparar, y a veces no concuerdan, pero se entiende que en la región que nos interesa, son tres ONGs, una fundación y una agencia internacional que ejecutaron las obras.

En Tumbes, Caritas recibió unos 67000 US \$. En Tumbes y Piura, la Fundación F. Ebert recibió unos 107000 US \$, sumando los aportes de esta fundación, de la Agencia Canadiense para el Desarrollo. de la Embajada de Francia en Ecuador y del Fondo Binacional. En Piura, CARE-Perú recibió 180000 US \$ del Fondo Binacional y unos 110000 US \$ de la US-AID, lo que da un total aproximado de unos 290000 US \$; CIPCA 120000 US \$ del Fondo Binacional, más unos 30000 US \$ de fondos locales y otros, sumando más de 150000 US \$. En Cajamarca el mismo CIPCA recibió unos 200000 US \$ del Fondo Binacional, y otros 150000 US \$ de locales y otros, llegando a un aproximado de 350000 US \$. En Amazonas el PNUD hubiera recibido 220000 US $\$$ del Fondo Binacional, no se sabe cuanto de otros.

Con estas sumas se construyen pozos anillados, muchas letrinas, unas cuantas aulas escolares, se abren algunas trochas carrozables, se instala una balsa o una mini central hidroeléctrica. También se implementa una que otra posta de inseminación artificial de ganado caprino o vacuno, así como un botiquín veterinario. Se limpian unas hectáreas de borrachera, una planta nociva para las cabras que volverá a crecer, se dan unos cuantos módulos para producir miel. También se distribuyen insumos para el cultivo de cebollas o para secar el café o se reparten plantones de cacao, se distribuyen unas diez maquinas de coser, se capacitan un grupo de lideres, otro de campesinos y algunas madres. No hay que olvidar un intercambio juvenil, financiado por el Fondo Binacional, 10000 US \$, la Agencia Canadiense para el Desarrollo, 40075 US \$, la fundación F. Ebert-Perú, 29420 US \$ y F. Ebert-Ecuador 15190 US \$, la Embajada de Francia Ecuador, un monto de 106980 US \$ para que 112 jóvenes puedan visitar el otro lado de la frontera. De hecho el listado de los proyectos, independientes y esparcidos a lo largo de la frontera, resulta algo surrealista (Plan Binacional, 2001, Capítulo Peruano).

CARE es la ONG, Organización No Grata como dicen unos entendidos en materia de desarrollo, que ganó el concurso para manejar, de los dos lados de la frontera, los recursos que US-AID ha donado. Es una organización de "Cooperación y Asistencia de Remesas al Exterior" creada en los Estados Unidos durante la segunda guerra mundial. Llegó en la frontera en tiempos del cólera, en 1991, y volvió a esta zona, en 1999, para trabajar tanto del lado ecuatoriano como del lado peruano. El CIPCA, "Centro de Investigación y Promoción del Campesinado de Piura" es una ONG fundada por los jesuitas después de la reforma agraria.

\section{5. En resumen}

Llegando al final de la lectura detallada de los documentos firmados en Brasilia en 1998, quisiéramos constatar con el lector que están redactados en un lenguaje diplomático supranacional, que utiliza términos como "desarrollo sustentable" o "conservación del medio ambiente", siguiendo lemas generados por tecnócratas del 
consenso de Washington, promovidos en conferencias de las Naciones Unidas, en cumbres presidenciales y repetidos en programas estatales, propuestas de la sociedad civil y proyectos de ONGs. Mensajes que sobreentienden intenciones, algo más cínicas, de luchar "contra la pobreza", de asegurar "la seguridad alimentaría", de reconocer "los derechos humanos" o de erradicar "la corrupción", pero que nunca se llegan a realizar.

En los textos oficiales la "región fronteriza" sigue indefinida como siguen inimaginables las reales condiciones de vida así como los sueños o las pesadillas de sus diversas poblaciones y sus relaciones con las sociedades que conforman a nivel regional, nacional o internacional y mundial. Sabemos que esto no es casualidad, los autores de los acuerdos de paz son funcionarios estatales quienes, de espaldas a toda realidad, siguen las directivas de funcionarios internacionales que son a su vez condicionados por los lineamientos de agentes globalizados. Y los agentes globalizados, enmarcados en los esquemas neoliberales, aplican las reglas de juego establecidas a nivel mundial por sus poderosas instituciones. Por un lado, considerando flujos y desconociendo límites, deslocalizan y desterritorializan para unificar y dominar mejor, por otro lado, desarraigando y desubicando, desconsiderando especificidades regionales y nacionales, reconstruyendo si necesario identidades "comodines", reducen a la impotencia poblaciones, cada día más divididas entre redes que las instrumentalizan y comunidades que las encierran sin dejarlas comunicar, incapaces de definir sus propias y apropiadas perspectivas de futuro.

Enfoquemos ahora, con una perspectiva histórica de unos treinta y cinco años, la región fronteriza que definimos como nuestro objeto de estudio, tratando de constatar las diferencias y complementariedades transfronterizas e internas de ambos lados de la frontera que la caracterizan, sin perder de vista los marcos nacionales donde se inserta y tratando de indicar toda su complejidad.

\section{FRACTURAS, DIFERENCIAS Y COMPLEMENTARIEDADES TRANSFRONTERIZAS E INTERNAS DE AMBOS LADOS DE LA FRONTERA}

\section{1. En cuanto al entorno natural}

\section{1. 1. Una región de transición}

La región fronteriza puede dividirse en dos partes distintas, una de costa hasta los $500 \mathrm{~m}$ y otra de sierra que no alcanza los $4000 \mathrm{~m}$ de altura. En estas latitudes entre el litoral pacífico y la cordillera andina se extiende una planicie costera. Además la baja altitud general de las serranías confiere a esta región una posición de bisagra, por una parte entre el litoral y la Amazonia y, por otra parte, entre los Andes centrales y norteños. Se notan, sin embargo, diferencias climáticas y morfológicas entre un lado y otro de la frontera (Deler, 1987; 1991; Hocquenghem, 1998). Veamos.

\section{1. 2. Entre climas tropicales húmedo y seco}

En el litoral, desde el Golfo de Guayaquil en Ecuador y hasta Chiclayo en Perú, se pasa en una distancia de unos $300 \mathrm{~km}$, de los bosques siempre verdes del piedemonte 
de la vertiente occidental de la cordillera de los Andes, a un desierto, algo parecido al del Sahara, manifestación de una de las gradaciones ecológicas más fuertes del mundo. A estas latitudes comienza la disimetría entre los pisos ecológicos observados en las dos vertientes externas, occidentales y orientales de la cordillera, una disimetría que se va acentuando hacia el sur.

En la costa y el piedemonte pacífico, viniendo del norte y cruzando el río Tumbes, se pasa de un trópico húmedo a un trópico seco. Esto debido a la influencia de dos corrientes opuestas, la corriente caliente del Niño que desde el norte bordea el litoral ecuatoriano y la corriente fría de Humboldt que desde el sur sigue el litoral peruano. La zona de encuentro de estas dos corrientes se desplaza entre Punta Santa Elena, en Ecuador, y Punta Aguja, en Perú, trastocando los límites climáticos en la región donde se vive entre lluvias extraordinarias y temibles sequías.

\section{1. 3. Entre distintos ramales de la cordillera}

Si el clima de la costa ecuatoriana se distingue netamente del de la costa peruana, las serranías de Loja y Zamora-Chinchipe comparten condiciones climáticas similares a las de Ayabaca, Huancabamba, Jaén, San Ignacio y Condorcanqui. Es en cuanto a morfología que se puede establecer una diferencia entre la sierra peruana y ecuatoriana. Del lado ecuatoriano, la cordillera occidental se divide en varios ramales de alturas medianas y bajas que descienden rápidamente hacia la costa y ninguno de ellos alcanza los $3000 \mathrm{~m}$ de altitud. Del lado peruano, los ramales de Ayabaca, de los Altos de Frías, de Sallique y San Felipe, son más anchos y más altos, llegando uno de ellos a casi $3000 \mathrm{~m}$ y otro a unos $3700 \mathrm{~m}$.

Según la clasificación en ecorregiones de Brack (1986 a; b), en la región se goza de un mar tropical, con la corriente del Niño y de un mar frío, con la corriente de Humboldt, de un litoral de manglares y desierto pacífico, de una costa de bosque tropical del Pacífico, de bosques secos ecuatoriales, con sus dos formaciones bien distintas, algarrobal y ceibal, de selva alta en las dos vertientes andinas y de páramos en las cumbres. Es decir que la región presenta una extraordinaria diversidad de recursos naturales que permite la elaboración de una gran variedad de recursos culturales.

Si el objetivo de nuestra investigación es vislumbrar problemas y posibilidades de desarrollo e integración del territorio y de la sociedad fronteriza, considerando el impacto de los cambios inducidos por el proceso de globalización, debemos reconocer también que las huellas de la historia reciente marcan en forma diferenciada la región. Es necesario por lo tanto tomar en cuenta los eventos que orientan, desde más de tres decenios, las evoluciones y transformaciones de un lado y de otro de la frontera.

\section{2. En cuanto a la historia reciente}

\section{2. 1. Dos procesos de modernización 1968-1989}

Convergencias y divergencias políticas

Durante unos veinte años, de 1968 a 1989, a pesar de dos modelos ideológicos opuestos, impuestos en América latina desde los centros de poder de Estados Unidos y 
de la Unión Soviética, la evolución de los dos países converge y difiere, según dinámicas nacionales propias.

En 1968, bajo el mando del general Juan Velasco Alvarado, las fuerzas armadas peruanas, como institución, toman el poder conformando el "Gobierno Revolucionario de las Fuerzas Armadas”. Un gobierno golpista de orientación progresista, ni capitalista ni comunista, pero en contra del imperialismo norteamericano. Los militares proponen reformas de las estructuras políticas, económicas y sociales, con miras a una modernización del país, basada en una reorganización de las fuerzas productivas. Este gobierno tiene en mente un modelo de desarrollo nacional alternativo al modelo de seguridad nacional, elaborado por la dictadura brasileña que adoptan luego, por ejemplo, las dictaduras de Banzer en Bolivia, de Pinochet en Chile y de Videla en Argentina (Comblin, 1977: 113-158).

Siguiendo el ejemplo peruano, las fuerzas armadas ecuatorianas intervienen en 1972 en la escena política, conformando el "Gobierno Nacionalista Revolucionario de las Fuerzas Armadas” presidido por el general Guillermo Rodríguez Lara. El gobierno militar proclama sus "Principios y Plan de Acción", definiéndose como "popular, antifeudal, anti-oligárquico, programador y de desarrollo autónomo". Propone "transformaciones sustanciales en el orden socio-económico y jurídico de la República" y una acción "enérgica contra los grupos socialmente y económicamente privilegiados" (Hurtado, 1977: 269-281).

Existe por lo tanto una convergencia ideológica "nacionalista y revolucionaria" entre los gobiernos peruanos y ecuatorianos frente a la ideología anti-comunista y proimperialista dependiente de los Estados Unidos de Norte América. A pesar de que los gobiernos de Ecuador y de Perú comparten un mismo modelo de desarrollo nacional, sus políticas de defensa varían y sus reformas tienen impactos diferenciados. Y en cuanto a las políticas de frontera, son opuestas, de fronteras vivas al norte y de inercia al sur.

Del lado peruano en 1968 el general Juan Velasco Alvarado nacionaliza los yacimientos petroleros, en 1969 promulga la ley de reforma agraria y en 1970 la ley de comunidades industriales. Una grave enfermedad lo debilita y las fuerzas armadas lo reemplazan por el general Francisco Morales Bermúdez Cerruti en 1975. Los militares se entrampan entre sus discursos y las realidades internas e internacionales, apreciando la bipolaridad norte/sur a la escala del conflicto por la hegemonía entre Este y Oeste, cuando las relaciones entre Perú y Estados Unidos no tienen comparación con las que existen entre la Unión Soviética y los Estados Unidos. Es más, la aplicación a la política de un simple plan estratégico, considerando la sociedad como un regimiento o una empresa, conduce a un voluntarismo ciego frente a variables políticas, económicas, sociales y culturales y al fracaso del modelo propuesto. Se inicia entonces una involución en la revolución, Morales Bermúdez paraliza las reformas estructurales lanzadas por Velasco. En 1977 movimientos masivos de protestas logran imponer un cronograma de retorno a la democracia. En 1978 se elige la Asamblea Constituyente y su presidente, Víctor Raúl Haya de la Torre, firma la Constitución de 1979. En 1980 es electo presidente de la República Fernando Belaunde Terry, lider de Acción Popular derrocado en 1968 por los militares. Hay que recordar que en estas elecciones el Partido Comunista del Perú-Sendero Luminoso irrumpe violentamente en la escena pública, 
quemando las ánforas en el pueblo de Chuschis en Ayacucho. En 1985 es electo el presidente Alan García Pérez, con una mayoría absoluta de la Alianza Popular Revolucionaria Americana, APRA. El desconocimiento de la deuda externa por el presidente Alan García en 1985, la acelerada devaluación de la moneda nacional en 1987, y la voluntad presidencial de nacionalizar la banca, para democratizar el crédito, deja el país al borde de la bancarrota en 1989. Los peruanos, después de un período de relativa estabilidad, entre 1968 y 1975, sufren de una recesión económica y de la violencia política que se desata en los años 80 .

Del lado ecuatoriano, a partir de 1972, el país comienza a producir petróleo y pasa a ser el segundo exportador del continente después de Venezuela. Ambos países se integran a la Organización de Países Exportadores de Petróleo, OPEP. El gobierno militar aprovecha la bonanza económica, debida al boom petrolero, para modernizar el país, lanzando amplios programas de infraestructuras, pero sin alterar profundamente las modalidades de tenencia de la tierra. Sin embargo diversos factores provocan el deterioro de un régimen militar que se proponía gobernar 30 años. La no realización de las reformas anunciadas, por falta de unidad en las fuerzas armadas divididas entre una tendencia peruana, reformista, y una tendencia brasileña, derechista, así como la intervención de la CIA, hacen perder al gobierno el apoyo de importantes sectores populares organizados y de partidos progresistas. El presidente Rodríguez Lara, como dictador, se opone a una restauración democrática y es derrocado en 1976 por las propias fuerzas armadas. Un triunvirato militar lo reemplaza, anunciando la intención de devolver el poder en un plazo de dos años, a través de elecciones libres. En 1978 una nueva constitución se aprueba por referéndum y es elegido presidente Jaime Roldós, un populista, que muere accidentalmente en 1981 dejando la posta a Osvaldo Hurtado, su aliado demócrata cristiano. En 1984, León Febres Cordero un agro-exportador liberal es electo presidente y le sucede, en 1988, el social-demócrata Rodrigo Borja. Los ecuatoriano sufren políticas constantes de ajustes estructurales parciales definidas alternativamente por gobiernos de corte social-demócrata y neoliberal que guardaron todos una política de subsidios, en cuanto a gas y gasolina en particular. Los primeros apoyando políticas de redistribución de la riqueza, los segundos beneficiando una acumulación en las empresas exportadoras.

\section{Rupturas peruanas y continuidades ecuatorianas}

Es necesario detenerse un momento sobre la drástica reforma agraria de 1969, decretada por el general Velasco y sobre sus consecuencias, en particular en cuanto a sistemas de producción en el extremo norte peruano. La reforma agraria cambia definitivamente las estructuras políticas, económicas, sociales y culturales peruanas. Acaba con las haciendas, un sistema de tenencia de la tierra de origen colonial, elimina la casta de los terratenientes cuna de las elites locales. Considerando la sociedad peruana como una sociedad de clase, el gobierno militar intenta borrar las diferencias étnicas y quienes trabajan la tierra, sin distinción de razas, son campesinos. Las comunidades indígenas, cuyos orígenes remontan a los pueblos de indios coloniales y que las leyes bolivarianas de la independencia transformaron, cambian una vez más de nombres, en la costa y en la sierra pasan a denominarse comunidades campesinas. Simbólicamente 
el 24 de junio, antes Día del Indio, pasa a ser Día del Campesino y aniversario de la reforma agraria. El término indígena o nativo sólo se conserva en relación a las comunidades amazónicas. En las tierras expropiadas a los latifundistas se promueven empresas de corte cooperativo manejadas por una tecno-burocracia estatal. El gobierno militar acentúa el rol planificador del aparato estatal, el control y la extracción de los recursos naturales, maneja las infraestructuras de producción, los sistemas de riego y de comunicación, la producción y distribución de energía e impulsa una economía proteccionista basada en el modelo de sustitución de importaciones. Se reestructura, de acuerdo al modelo militar, en forma vertical a partir de las instituciones de un Estado centralizado, el conjunto de la sociedad peruana y por lo tanto la sociedad regional del extremo norte del Perú.

Este renovado orden autoritario, al no tomar en cuenta las especificidades locales y departamentales, al no concertar con la población, impide que se conforme una sociedad democrática, que se genere desde la base una organización social fundada sobre la cooperación y que se implementen medios de producción adaptados a las diferentes realidades del país. Bloquea también el análisis independiente de las relaciones entre sector público y privado, entre intereses individuales y colectivos y, priorizando una visión de clase, pretende borrar las identidades, distorsionando así la búsqueda de puntos de convergencia y la reflexión sobre acciones y proyectos autónomos. Es decir impide que se defina en forma democrática un futuro posible para el país.

En el extremo norte del Perú, los hacendados producían algodón para el mercado internacional y ganado para el mercado nacional. Con la reforma agraria se pierde la ganadería costeña, pero el gobierno militar realiza en la costa obras públicas, bases tanto de una ampliación de la frontera agrícola, con la represa de Poechos y la red de canales de riego del Chira al Piura, así como del desarrollo de las actividades pesqueras de extracción y de transformación, con el complejo de Paita. Momentáneamente las nuevas fuentes de empleo logran satisfacer algunas necesidades familiares y laborales de una población en aumento. Las haciendas serranas, ante todo ganaderas, requerían poca mano de obra y expulsaban sus yanaconas hacia la costa. Con la reforma agraria la sierra pierde su ganadería y pasa a una producción agrícola ante todo de subsistencia y por lo tanto los serranos dejan de migrar. Una de las consecuencias de la reforma agraria, que en este caso se conjuga con otros factores es el notable crecimiento demográfico que se observa, por razones diferentes en la sierra y en la costa. Otra consecuencia de esta reforma en el extremo norte andino es el desarrollo desigual entre una sierra, olvidada por el gobierno militar, y una costa, donde este gobierno invierte en las infraestructuras productivas de los valles y del litoral (Huber, 1995; Apel, 1996; Hocquenghem, 1998).

En Ecuador se mantiene el sistema de tenencia de la tierra y las condiciones laborales de los campesinos no varían tan bruscamente. Es de notar, muy esquemáticamente, que las reformas tienden a limitar las prerrogativas y a evitar los abusos de los latifundistas, pero muchos terratenientes conservan la conducción de sus haciendas y las elites locales no se desmoronan como en el Perú. Así mismo 
se mantiene de cierta forma el sistema de castas, por lo tanto se reconoce abiertamente la diversidad étnica, y al centralismo estatal no deja de oponerse un movimiento descentralista, enraizado en sociedades regionales conscientes de sus identidades propias. Ahí juega un papel importante la bipolaridad nacional entre Quito y Guayaquil que deja espacio para otros centros regionales como Cuenca o en menor grado Portoviejo y Loja. En cuanto a la inversión para la modernización del país, más que las grandes obras de infraestructura para la producción, que conducen en el Perú a un desarrollo desigual entre la costa, la sierra y la Amazonia, los militares ecuatorianos invierten en mejorar la cobertura de servicios, sistemas de comunicación y de distribución de energía, lo que permite integrar el país y modernizar la producción. La política de fronteras vivas de los militares abre nuevos horizontes a los migrantes serranos, apoyada en la política de Colonización que es la otra faz de la política de Reforma Agraria. De hecho al flujo migratorio que drena los huasipungos, en particular los lojanos, hacia las plantaciones, luego las empresas acuícolas, camaroneras y langostineras, así como las empresas agro-industriales de las provincias del Oro y Guayas, y también hacía Tumbes y Piura donde los migrantes se enraízan como negociantes, se agrega un nuevo canal de migración que conduce hacia las vertientes amazónicas y las zonas de frontera (Gondard \& Mazurek, 2001: 17).

Durante la década de los 90, en Ecuador, en Perú y en la región fronteriza que nos interesa, como en todo el mundo, se dejan sentir, modulados por los diferentes contextos nacionales, regionales y locales, los diversos impactos de la globalización, objetos de nuestra investigación. Trataremos de percibirlos y analizarlos con más precisión a medida que avance el estudio, pero es necesario señalar desde ahora algunos de los más notables de estos impactos.

\section{2. 2. El impacto de la globalización 1989-2001}

Neoliberalismo y pensamiento hegemónico

Como es conocido, el proceso de globalización de los mercados financieros internacionales se deja sentir a partir del colapso del sistema de Bretton Woods en 1973, la economía global de mercado se extiende y homogeneiza a raíz del desmoronamiento de los estados socialistas y la caída del muro de Berlín en 1989. Una globalización que los economistas neoliberales presentan como ineluctable e imponen como marco de referencia para todo programa de desarrollo. Esto minimizando el rol del Estado y de los sectores públicos, desvirtuando sus políticas sociales y ambientales así como sus planes de desarrollo, dejando las reglas del libre mercado y las aspiraciones del sector privado orientar la gestión estratégica de los recursos naturales y culturales.

Y este proceso de globalización, según los esquemas neoliberales, genera una reacción, desde una óptica crítica con respecto al mercado, al capitalismo, y a un pensamiento hegemónico que implicaría la derrota definitiva de la política y de las estrategias de reforma social frente a la primacía de la economía global. Una crítica que arriesga limitarse a una reedición revisada de los argumentos de la teoría de la dependencia, bloqueando la creatividad intelectual que hace falta para encarar todas las facetas inéditas de este proceso, los diversos contextos en los cuales se puede observar y las múltiples dimensiones de sus impactos (Messner, 2000). 


\section{Crisis económicas, políticas y sociales}

En 1990 los peruanos eligen como presidente a Alberto Fujimori Fujimori, un ingeniero que llegó a ser rector de la Universidad Nacional Agraria La Molina, de hecho un advenedizo, desconocido en los medios de la política y sin partido. Fujimori presenta un programa aparentemente opuesto al ajuste estructural dictado por la tríada de Washington, Fondo Monetario Internacional, FMI, Banco Interamericano de Desarrollo, BID, y Banco Mundial, BM. Pero, a pesar de sus promesas electorales de cambios graduales en la economía, al inicio de su gobierno devalúa brutalmente, para sincerar los precios, lo que termina de aplastar la clase media, paraliza las inversiones y agudiza la recesión. Con el autogolpe del 5 de abril de 1992, queda aniquilada la división de poder entre ejecutivo, legislativo y judicial y se instala la autocracia. La mayoría de los votos acordados a Fujimori después del auto-golpe de 1992, en particular por las clases desfavorecidas, se explica por una desvalorización de la política, de la democracia representativa y de sus instituciones, así como por cierta eficiencia en cuanto al control de la violencia y de la crisis económica. De hecho Fujimori es reelecto por segunda vez en 1995, pero el año siguiente, las consecuencias del programa de ajuste económico hacen patentes sus límites, el descontento con las prácticas arbitrarias, las violaciones de los derechos humanos y de las instituciones democráticas, la impunidad de la cual goza la alta oficialidad militar, las relaciones con el tráfico de droga de personajes afines al presidente, como Vladimiro Montesinos, hacen caer el nivel de apreciación del gobierno. Finalmente los actos delictivos, para perpetuarse anticonstitucionalmente en el poder durante un tercer período de gobierno, se hacen patentes en 2000, ponen al descubierto el nivel de corrupción y la verdadera cara de quienes gobiernan el país desde una década. Las protestas de los peruanos en contra de elecciones fraudulentas, de las ONGs y otras asociaciones civiles, por ejemplo las que se preocupan por derechos humanos, que se manifiestan tanto a nivel local, nacional e internacional, así como las observaciones de la Organización de los Estados Americanos, OEA, conducen a la caída del gobierno mafioso. Montesinos y Fujimori huyen del país y asume la presidencia del gobierno de transición Valentín Paniagua de Acción Popular, AP. En 2001 es elegido presidente Alejandro Toledo, un economista formado en los Estados Unidos y sin partido (Dammert ed., 1993; Gastellu, 1994; Dollfus, 1997b; Balbi, 1997; 2000; Gonzales de Olarte, 1997; 2000; Burgos, 2000; Franco, 2000; Herrera, 2000; Jiménez, 2000).

Los ecuatorianos eligen en 1992 a Sixto Durán Ballén, otro neoliberal, quién adopta un programa de estabilización económica, devolviendo al Banco Central su responsabilidad en cuanto a política fiscal, austeridad en el gasto y reducción de los subsidios, medidas que, a corto plazo, logran su objetivo. Desafortunadamente a partir de 1995, Ecuador y Perú se enfrentan en una guerra no declarada y a mediados del mismo año el racionamiento energético afecta seriamente el aparato productivo durante un semestre. Finalmente el vicepresidente, cabeza de la gestión económica, comprometido en un escándalo de corrupción, fuga del país. Ecuador queda desestabilizado y en 1996 es elegido presidente Abdalá Bucaram cesado de sus funciones seis meses más tarde por el Congreso, por "incapacidad mental”. El mismo Congreso nombra a su titular Fabián Alarcón presidente interino de la Republíca por 18 meses. El gobierno interino no tiene 
la voluntad para mantener una política fiscal austera ni para llevar adelante una gestión económica ordenada. En 1998 las perspectivas económicas no son alentadoras, el precio del petróleo baja considerablemente y la economía ecuatoriana, extremadamente vulnerable sin las regalías petroleras, se ve fuertemente afectada. Además el fenómeno del niño destruye las infraestructuras y las plantaciones de la costa. En este contexto de crisis es electo Jamil Mahuad Witt, un demócrata cristiano, que no puede evitar la aplicación de medidas severas para superar el catastrófico estado de la economía que hereda y, precipitadamente, impone el dólar estadounidense como moneda nacional. La amplitud de la crisis financiera y económica revelada con la quiebra de 14 de los 42 bancos del país en 1999, causa una mayor recesión que se traduce por una degradación sensible tanto en las condiciones de vida como en el mantenimiento de las infraestructuras. La inflación permanente desemboca en la dolarización, conllevando a una alza de los costos de producción y a una baja del diferencial de cambio, que hasta hace poco resultaba favorable a los productos ecuatorianos. En enero 2000 el movimiento indígena, aliado con militares progresistas, derroca al gobierno de Mahuad y toma el poder por un lapso de dos horas. Es sustituido, por presiones de la cúpula militar y el gobierno de Estados Unidos, por el actual mandatario Gustavo Noboa Bejarano. Ninguno de los objetivos de la dolarización se cumple, la inflación se dispara y a fines del 2000 es la más alta de América Latina. Se incrementa la pobreza de los ecuatorianos ya golpeados por los ajustes de 1982 y la expropiación de sus ahorros durante el gobierno de Mahuad (Hurtado, 1997; CORDES, 1999; Tamayo, 2001).

En las ciudades ecuatorianas y peruanas se constata, por un lado, que la clase media al perder sus capacidades económicas, pierde obviamente su autonomía y por lo tanto sus capacidades de reacción y, por otro lado, que surge una categoría de nuevos ricos y se constituyen fortunas en base a actividades ilícitas, trafico de divisas, de coca, de armas, en un ambiente de corrupción generalizada. Después de la hiperinflación, la nueva plaga que azota los dos países y amenaza la democracia es la corrupción (Dammert, 1996; Otárola, 1996; Vargas Haya, 1996; von Gleich, 1996).

Lo impactante en ambos países es la promoción de un modelo neoliberal que incita los gobiernos a transferir los servicios públicos, responsabilidad del Estado, a las empresas privadas. Para esto se elaboran proyectos de reingeniería del aparato estatal, así como de leyes y reglamentos en cuanto a la gestión de los bienes públicos y comunes. Lo que tiende en realidad a socializar las pérdidas y a privatizar los beneficios.

El caso peruano es ejemplar, las grandes empresas transnacionales y nacionales tienen campo libre para negociar, a cualquier precio, aguas y tierras, minas y bosques. El Perú vuelve a ser ante todo exportador de materia prima y los beneficios de las empresas nacionales e internacionales se acumulan fuera del país, el sector minero es uno de los más favorecido. En toda la región fronteriza y en Piura se multiplican los denuncios mineros, se ponen en marcha los estudios de rentabilidad de la mina de oro de Tambogrande, se licitan los fosfatos de Bayovar. La situación que enfrentan los obreros petroleros de Talara es estremecedora: con la privatización de las empresas nacionalizadas por el gobierno militar, quedan sin trabajo, expuestos a la delincuencia, a la prostitución y a la droga.

La situación en el sector agrario vale un párrafo aparte, debido a su importancia en el Perú y en la región fronteriza. Es necesario recalcar que, a más de treinta años de 
la reforma agraria, se justifica una contra-reforma, en base a un discurso dominante, elaborado en el marco de los esquemas neoliberales, que en resumen deja entender que, inspirada en una utopía colectivista nefasta, la reforma del gobierno militar ha sido un fracaso, ha conducido a la ruina la agricultura peruana. Por lo tanto es urgente devolver un papel motor a los agricultores dinámicos que fueron expropiados, con el fin de que contribuyan a la reactivación del sector agro-exportador, por ejemplo modernizando la producción de algodón en Piura e impulsando nuevos productos, marigold, espárrago, entre otros. Cuando el neoliberalismo inspira la mayoría de las políticas económicas, este discurso, que deja de lado los múltiples factores que en el contexto socioeconómico de la época explican por qué la reforma no tuvo las consecuencias esperadas, permite hoy presentar a los campesinos como incapaces de adoptar nuevas tecnologías y sostener que la estructura productiva actual no podría perdurar sin perjudicar la competitividad del Perú. Aun, si un retorno a la situación anterior a 1969 parece excluida, la legislación reciente permite pensar que se desarrolla un proceso de nueva concentración de tierras y una nueva modalidad de gestión del agua que tienden a eliminar la agricultura familiar. Cualquier sea la política del nuevo gobierno del presidente Toledo, es poco probable que a corto plazo se pongan en práctica medidas intervencionistas (Mesclier, 2000).

En el extremo norte peruano la sierra sigue aislada y con el crecimiento de la población siguen dividiéndose tierras agotadas que no logran sustentar quienes no migran. En los valles piuranos y tumbesinos los impactos de la contra-reforma agraria se deja sentir en forma aguda. Los minifundistas desorganizados y marginados son reducidos a la condición de mano de obra barata. Los pequeños agricultores, beneficiarios de la parcelación de las tierras a fines de los años 80, pintados de pequeños empresarios quiebran rápidamente y venden sus predios, esto a raíz de la desaparición del banco agrario, en 1992, por falta de un necesario, oportuno y adecuado, crédito. Se constituyen entonces empresas en base a capital nacional e internacional que invierten en nuevas tecnologías, riego por aspersión o por goteo, que se relacionan con las redes de comercialización globalizadas y que, gracias a una "gestión estratégica" de su mano de obra y sus empleados, realizan cuantiosos beneficios (Dollfus \& Bourliaud, 1997).

\section{Migraciones, desestructuración social y corrupción}

La degradación de las condiciones económicas lleva las capas pauperizadas de la población, tanto rural como urbana, a distintas estrategias migratorias. Hay que recalcar que en el caso peruano, a la crisis económica se añade la inseguridad permanente causada por la violencia política. A partir de los años 80 , en este país, la migración de los campesinos, más que hacia al extranjero, se orienta por un lado hacia las ciudades y por otro lado hacia las zonas cocaleras en busca de plata fácil, enfrentando todos los peligros engendrados por la violencia desatada entre traficantes, guerrilleros, militares y policiales, para el control del negocio (Bourliaud et al., 1998). Mientras tanto los citadinos, entre estos parte de la elite intelectual, salen hacia los países del norte, Estados Unidos, Europa y Japón (Altamirano, 1992) .

En el caso específico de Piura y Tumbes, hemos visto que una de las consecuencias de la reforma agraria ha sido la estabilización de la población en base a una relativa 
seguridad alimentaria y sabemos que la región fronteriza no fue mayormente afectada por la guerra interna, por lo cual el proceso migratorio no se da con la misma amplitud que en el centro y sur del país. Es recién al fin de la década de los 80 que los campesinos piuranos y tumbesinos migran en busca de trabajo en la costa y fuera de sus departamentos (Barrera, et al., 1993; Mesclier, 1997). Y los piuranos serranos tienden a migrar en la vertiente amazónica de los Andes, en particular en las provincias fronterizas cajamarquinas de San Ignacio y Jaén, zonas cafetaleras, luego hacia Tocache y La Pólvora del departamento de San Martín, zonas cocaleras. Hoy invaden las tierras indígenas de la cordillera del Cóndor en los límites de la provincia amazónica de Condorcanqui. Actualmente la invasión piurana y ante todo cajamarquina de las tierras de los nativos provoca enfrentamientos mortales con los aguarunas. Es el caso de un grupo de la comunidad nativa de Los Naranjos quien, habiendo agotado las vías legales para defender su territorio y desesperado por la injusticia de autoridades corruptas, se levantó en arma contra los colonos de la localidad de Flor de la Frontera, en la provincia de San Ignacio el 17 de enero 2002, dejando 15 muertos entre los invasores y perdiendo, según informaciones no publicadas, unos cinco de sus comuneros (Etecé, 2002).

En Ecuador, los motivos, los destinos y los impactos de la emigración, son otros. Las sucesivas crisis económicas acrecientan la migración de campesinos y de citadinos hacia los países del norte, si bien la ola actual corre más hacia Europa, España en particular. A diferencia de Piura y Tumbes, este proceso migratorio se deja sentir fuertemente en la provincia de Loja. Esta provincia es un foco de expulsión de la población rural en busca de trabajo, y actualmente en ciertos barrios, denominación lojana de caseríos, más de $30 \%$ de los jóvenes adultos están en España. Este éxodo masivo que trae importantes remesas financieras al país, desestabiliza totalmente las estructuras familiares, el mercado local del trabajo y por consiguiente la economía regional y engendra graves problemas socioculturales. La responsabilidad de la educación de la nueva generación la asumen abuelos u otros familiares que carecen de la debida autoridad. Además, la plata que envían los padres a sus hijos, fuera de proporción con el nivel económico local, trastornan y desubican a niños y adolescentes. De hecho los problemas de alcoholismo, droga, delincuencia y prostitución juvenil aumentan en forma preocupante en el campo y las pequeñas ciudades.

Ahora bién, los peruanos descubren en 2000 otra faz de la globalización, el poder de corrupción de un gobierno mafioso comprometido con redes supranacionales de traficantes de drogas y de armas, rodeado de allegados, ayayeros, jalalevas o coberos, según las latitudes, implicados en los negocios más repugnantes y sórdidos. Frente a tal calamidad la población enfrenta la cleptocracia, demuestra al mundo el nivel de corrupción alcanzado por sus gobernantes que pierden sus respaldos globalizados, y derroca a la dupla Fujimori-Montesinos (Dammert, 2001b).

\section{Participación, integración y descentralización}

La constatación de los desastrosos impactos sociales de la globalización, la búsqueda de medios para contrarrestar un proceso que conduce a la exclusión, fuerzan a renovados análisis de las transformaciones de todas las categorías políticas, a nuevos interrogantes en cuanto a una supuesta progresiva, pero irreversible desestatización de 
la sociedad nacional y desnacionalización del Estado. Lo que da lugar a imaginaciones diversas, desde nacionalidades sin nación hasta naciones y nacionalidades sin Estado, pasando por visiones de entidades caóticas ingobernables, poderes globales, alto clero supranacional, economías no viables humanamente a varias escalas. De hecho tanto en Ecuador como en Perú, en los países andinos como en toda América latina y el resto del mundo, se requiere repensar el rol del Estado, las relaciones entre el sector público y privado, las formas de gobierno $\mathrm{y}$, en particular, los fundamentos y las condiciones necesarias y suficientes de una democracia representativa, y esto tanto a nivel regional, nacional como global (Guzmán, 1996; Pachano, 1998; de Rivero, 1998; Sánchez Parga, 1999; Balbi, 2000; Franco, 2000).

Este esfuerzo de reflexión pone en evidencia las diferencias de orden político, socioeconómico y cultural que fragmentan la sociedad en todos sus niveles, hasta el individual, generando conciencias de diversas identidades multifacéticas que a su vez la quebrantan según otros ejes, incitando a reflexionar sobre la identidad, los efectos del centralismo y las necesidades de participación, integración y descentralización (Neira, 1996; Adoum, 1997; Donoso, 1998; Carranza, 2000).

Otra vez, los procesos de participación, integración y descentralización se dan en contextos muy diferentes en Ecuador y en Perú. En Ecuador el movimiento descentralista tiene raíces históricas en las provincias y desde 1989 se fortalece la autonomía de las instituciones locales y regionales. La sociedad organizada en partidos, gremios, movimientos étnicos, ONGs, y otras formas de asociaciones participa, al menos reaccionando, en las políticas locales, regionales y nacionales. Al contrario, en el Perú la autocracia fujimorista impone un hipercentralismo perverso que ahoga las potencialidades de las diversas regiones. Aplicando los esquemas neoliberales que sustentan el proceso de globalización, por medio del terrorismo estatal y de la corrupción, la dupla Fujimori-Montesinos y sus lacayos logran controlar las fuerzas armadas y gran parte de los medios de comunicación masivos, aliarse parte de la jerarquía eclesiástica, desestructurar partidos y gremios, infiltrar y conducir a la impotencia las ONGs y otras asociaciones, por lo tanto reducir al mínimo las capacidades de participación social. Es cierto, el gobierno de Alejandro Toledo está dando inicio a nuevos procesos de participación, integración y descentralización, convoca todas las fuerzas sociales y anuncia elecciones regionales en cada departamento, pero la descentralización es un instrumento de doble filo difícil de manejar en un contexto neoliberal.

La descentralización pretende ampliar la participación ciudadana en la toma de decisiones por medio de una nueva repartición del poder a nivel municipal y regional, pero una autonomía política sin autonomía económica que la garantice no permite una real participación. Y bajo la aparente apertura que ofrece el libre mercado, como regulador de la oferta y de la demanda, la participación está condicionada por el capital. La descentralización obliga a repensar las relaciones entre espacios, territorios y sociedades, pero en un marco neoliberal, el reordenamiento territorial amenaza ser excluyente. Por lo tanto es central idear un proceso de descentralización que permita el desarrollo y la integración de las regiones, entre otras la fronteriza, en beneficio de la población en su totalidad, de acuerdo con un plan de gestión de los recursos regionales, 
pero en el marco de un plan de gestión de los recursos nacionales. Es más, ¿cómo evitar la conformación de cacicazgos? La descentralización arriesga atomizar las instancias de gobierno y fragilizar las estructuras estatales, al minimizar las funciones ejecutivas del Estado reduciéndolo a sus funciones normativas, lo que es uno de los objetivos de las políticas neoliberales. Por lo tanto para contrarrestarlas es necesario definir claramente los distintos niveles de responsabilidades, competencias y recursos necesarios para ejercer el poder y formar, desde la escuela primaria hasta la universidad, ciudadanos, funcionarios y gobernantes, conscientes de sus derechos y deberes así como de las potencialidades y limitaciones específicas del entorno donde viven (Boisier, 1992; Dammert, 1992; 1999; 2001a; Planas, 1998; Zas Friz, 1998; 2001; Hocquenghem, 1998; 2001; Hocquenghem \& Dammert, 1999; Durt, 2001a).

Pensamiento único, maniqueísmo y horror planetario

Finalmente, recordando que los procesos de globalización tienden a unificar imponiendo una ideología hegemónica, surge una inquietud: ¿en el Perú, donde desde tiempos prehispánicos, durante la Colonia y la República sigue imperando el principio de autoridad y el respeto del orden jerárquico, cómo imaginar un porvenir democrático?

No hay que olvidar que concomitante a la salida del gobierno militar autoritario, en 1980, surgen movimientos terroristas totalitarios, Partido Comunista del PerúSendero Luminoso, PCP-SL y Movimiento Revolucionario Tupac Amarú, MRTA. El pensamiento único pretende regir y perpetuarse, si bien con signos opuestos. Luego, en 1990 con el gobierno del presidente Alberto Fujimori, se impone en el Perú el nuevo orden antisubversivo nacional, el neoliberalismo globalizado y el pragmatismo político mundializado a largo plazo. El país sufre entonces otra década de concentración de poder que desestructura toda forma de organización social no controlada por la presidencia.

En 2000, después de la caída de la dupla Fujimori-Montesinos, en el Perú se requiere contribuir a una reestructuración de las instituciones públicas y privadas, a una redefinición de sus roles y relaciones con miras a la elaboración e implementación de políticas sociales. El gobierno de transición del presidente Valentín Paniagua inicia una restauración de las instituciones democráticas, el país se encamina hacia el reconocimiento de los derechos humanos, étnicos y culturales, una senda que pretende seguir el nuevo gobierno del presidente Alejandro Toledo. Pero, ¿no será esta reorientación otra manifestación del pensamiento único? Las mesas de concertación, las comisiones de la verdad, las iniciativas de lucha contra la pobreza, las organizaciones de protección y de conservación del medio ambiente, que se multiplican, ¿no serán parte de un engañoso discurso mundializado, cuando en realidad, en silencio, cada día, en cada lugar y como siempre, pero de manera cada vez más evidente, se sufre toda suerte de violencias, se viven innumerables formas de guerras y incalculables casos de injusticias, se profundizan las desigualdades sociales y se agudizan riesgos ambientales.

En septiembre 2001 caen las torres del World Trade Center de New York, símbolo del poder del capital globalizado y de la hegemonía mundializada del gobierno norteamericano. Una caída puesta en escena por CNN que difunde una imagen y un 
discurso maniqueístas, oponiendo los arquetipos del bien y del mal, de dios y del diablo, del dogmatismo cristiano y del fanatismo musulmán. De dos ideologías que se oponían de un lado y de otro de la cortina de hierro, se pasa a proyectar donde sea en el planeta dos perspectivas igualmente totalitarias de un mundo sin fronteras nuevamente polarizado. Dos perspectivas de poder absoluto que intentan saturar el horizonte generando un horror mundializado, en nombre de la justicia infinita o de la guerra santa. En contra del ejercicio de la violencia terrorista y de la venganza atroz se conjugan, desde otros puntos de vistas, tolerantes, libertarios, democráticos, las fuerzas de quienes gritan "basta ya" de todos los abusos de donde vengan, exigiendo inteligencia para tratar de entender lo que esta pasando, respeto por el otro, consideración por la primacía del hombre sobre lo económico, voluntad para revisar los esquemas neoliberales, asícomo para contrarrestar el pensamiento hegemónico, e imaginación para idear modelos de desarrollo e integración social humanamente aceptables, que permitan vivir juntos, iguales pero diferentes.

Un objetivo que implica en cada sitio y momento, con miradas cruzadas, considerar a diversas escalas las diferentes facetas de las múltiples realidades del entorno natural y social y sus peculiares historias, para tratar de comprender todas las consecuencias de un proceso histórico que abarca y conecta los ámbitos, en perpetua evolución y transformación, de lo económico, lo estratégico, lo político, lo social, lo cultural, lo identitario. Un proceso que trastoca los límites territoriales, altera los niveles de interrelaciones entre estados, naciones, pueblos, individuos, cambia por medio de nuevas tecnologías la relación entre la sociedad y la naturaleza. Un proceso cuyos impactos se dejan sentir en todas las esferas de la vida en el planeta como resultantes del intercambio generalizado entre las diferentes partes del mundo, el espacio global siendo el espacio de transacción de la humanidad.

\section{3. En cuanto a la población y al ordenamiento territorial}

\section{3. 1. Diversidad étnica y densidad poblacional}

En la región que nos interesa, del lado ecuatoriano la población es mestiza de habla castellana, salvo en las serranías de Saraguro, al norte de Loja, donde los saraguros se reconocen como indígenas y hablan quechua y en el piedemonte oriental donde los shuares y ashuares pertenecen al grupo jívaro. Del lado peruano, la población se considera mestiza y sólo habla castellano. Sin embargo es de notar que la mayoría de los campesinos del valle de Piura son descendientes de poblaciones indígenas costeñas, que conviven en el alto Piura con descendientes de esclavos africanos, que en los páramos y valles secos interandinos quedan descendientes de mitimaes quechua-hablantes, y que en la vertiente amazónica de la cordillera de los Andes viven los aguarunas y huambisas de afiliación jívara. Se debe subrayar una diferencia notable entre los dos países que se refiere al reconocimiento de la diversidad étnica y cultural. Actualmente en Ecuador existe un movimiento indígena que participa activamente en la vida política del país, mientras que en Perú sólo se percibe en forma incipiente en el sur y en la Amazonia.

Otra diferencia se relaciona con la densidad poblacional. En Ecuador el tejido político administrativo constituye una malla más fina que en Perú, a consecuencia de una mayor densidad de población. Y hay que recordar el resultado de una política de 
fronteras vivas en Ecuador y de abandono de las fronteras en el Perú: a lo largo de la frontera, la población ecuatoriana es algo más densa que del lado peruano.

En cuanto a población, según los últimos censos, en Ecuador la provincia de El Oro cuenta con 412572 habitantes, la de Loja con 38 498, la de Zamora-Chinchipe con 66167 y la de Morona-Santiago 84 216. En el Perú el departamento de Tumbes cuenta con 196602 habitantes, el de Piura con 1588 716, el de Cajamarca con 1449075 y el de Amazonas con 416280.

\section{3. 2. Autoridades políticas y administrativas}

En cuanto al ordenamiento del territorio ecuatoriano se divide en provincias, cantones y parroquias, urbanas y rurales y, a un nivel más pequeño, caseríos, llamados barrios en Loja. Esta división tiene su homóloga en Perú con los departamentos, provincias y distritos, con sus respectivos caseríos. A cada nivel de gestión territorial corresponden autoridades elegidas por la ciudadanía y autoridades nombradas por el gobierno central.

Los ciudadanos, mediante el sufragio universal, eligen a sus representantes. Según la Constitución Política de 1998, en Ecuador, las autoridades electas en el ámbito provincial son el prefecto, elegido por el pueblo, y el consejo provincial, elegido por mitad al sufragio universal y la otra mitad por elección indirecta de los concejos municipales. No tienen equivalentes en Perú, según la Constitución de 1993.

En Ecuador, en el ámbito cantonal, la población elige al alcalde quien ejerce la presidencia del concejo municipal. El concejo municipal, elegido por el pueblo, elige a su vez y en su seno su vicepresidente, que hace las veces de alcalde en ausencia de este. En el Perú la población elige igualmente al alcalde provincial y a su concejo. Finalmente, en Ecuador, a nivel únicamente de parroquias rurales, la población elige una junta parroquial cuyo presidente es el elegido con mayor votación. En el Perú la población elige al alcalde distrital y a su concejo.

La presidencia de la República designa sus representantes. En Ecuador, en el ámbito provincial, se nombra el Gobernador, que corresponde, a nivel departamental, al Prefecto peruano. En este país, el gobierno designa el Presidente del Consejo Transitorio de Administración Regional, CTAR, que tiene como ámbito territorial el departamento. En Ecuador en el ámbito cantonal, el delegado del gobernador es el jefe político y a nivel parroquial el teniente político. En el Perú, en el ámbito provincial, el delegado es el subprefecto y en el ámbito distrital es el teniente gobernador.

A las autoridades elegidas por la ciudadanía o designadas por el gobierno se suman, en el escenario regional de cada país, una multiplicidad de actores representantes de organizaciones sean políticas, gremiales, no gubernamentales, así como funcionarios y empleados, tanto del sector público como privado, nacional, supranacional o internacional. El papel que, en cuanto al desarrollo y la integración de la región fronteriza, juegan estos actores en sus respectivas instituciones será considerado en una segunda etapa de esta investigación.

Pasemos a ver las diferencias y complementariedades en cuanto a los sistemas de producción y las actividades económicas en base a estudios realizados en el marco de 
programas del IRD (ex ORSTOM) y del CNRS-IFEA (Gondard, 1983a, b, c; Hocquenghem, 1990; 1998; Hocquenghem \& Lanning et al., 1999; Huttel et al., 1999).

\section{4. En cuanto a las actividades económicas}

\section{4. 1. El sector primario: la producción}

Es preciso recordar, en primer lugar, que la diferencia altitudinal entre la sierra ecuatoriana y peruana influye, en particular, sobre la producción agropecuaria. Del lado ecuatoriano, salvo en el cantón Saraguro, no hay producción de altura, mientras que del lado peruano se siembran papas, ocas, habas, cebada y trigo. En segundo lugar no hay que olvidar que en Ecuador se conserva la dualidad hacienda-pequeña propiedad y que en el Perú se siguen parcelando las tierras en la sierra y se vislumbra la reconstitución de grandes empresas agro-ganaderas en la costa.

En Ecuador, las haciendas costeras producen ante todo banano para el mercado internacional, en tanto que en la sierra, las haciendas son más ganaderas y las pequeñas propiedades más agrícolas. En los valles bajos se siembran arroz, yuca, maíz duro, maní y más arriba, café, guineo y maíz duro. Las pequeñas propiedades, en las partes secas y calientes, tienen algo de ganado caprino, en cambio en las zonas más altas y más húmedas, ganado bovino. Es de notar que el café se cultiva de los dos lados de la frontera en las vertientes externas de los Andes y actualmente esta producción se moderniza en toda la región fronteriza.

En Perú, los valles irrigados de la costa producen para la exportación y el mercado nacional algodón, maíz duro, arroz, espárrago, marigold, limón y mango. Se cría ganado caprino y algo de ganado vacuno en el bosque seco. En la sierra, en los diferentes pisos altitudinales, se siembra para el autoconsumo y algo de excedentes que aprovisiona el mercado de Piura. Se siembra arroz y maíz duro en los valles bajos y calientes del piedemonte. Hacia arriba, se cultiva caña de azúcar, guineo, yuca y café; más alto, en el piso más templado y más húmedo, maíz criollo, amiláceo blando, junto con fréjoles, en las alturas frías y húmedas, ocas, papas, habas así como cebada y trigo. Hay también ganado caprino en la parte baja del piedemonte, ganado vacuno criollo y chanchos cebados con maíz local en la parte alta. En las zonas aisladas del piedemonte amazónico tiende a extenderse por el alto Marañón, viniendo de San Martín hacía Saramiriza, San Borga, las plantaciones ilícitas de coca y actualmente de amapola.

En cuanto a las actividades de extracción, en la costa de ambas partes de la frontera, se nota una fuerte actividad centrada en la pesca artesanal e industrial, así como al aprovechamiento de los manglares y de las camaroneras o langostineras. Estos productos marinos alimentan los mercados nacionales e internacionales.

La extracción minera en Ecuador se realiza básicamente a nivel artesanal, en torno a las minas de oro, en la vertiente oriental de la cordillera, si bien parece que en la vertiente occidental renace la actividad minera en Zaruma. En Perú la explotación petrolera se industrializó desde fines del siglo XIX y en la segunda mitad del siglo XX. La explotación de los fosfatos de Bayóvar y de la mina de oro y otros metales de Tambogrande, se perfila como posibilidad de una importante actividad minera. 


\section{4. 2. El sector secundario: las actividades de transformación}

En cuanto al sector secundario, la agroindustria es el elemento esencial de la actividad de uno y otro lado de la frontera.

En la costa ecuatoriana a partir del maíz duro, producido en la sierra y procesado en Machala, Santa Rosa y Balsas, se elaboran alimentos balanceados requeridos por las explotaciones avícolas. En la sierra, a partir de la caña, se elabora azúcar en el ingenio de Catamayo. Además existen empresas congeladoras y enlatadoras de productos marinos para la exportación.

Del lado peruano, la pesca industrial en Paita es la base de la elaboración de harina de pescado, componente de los alimentos balanceados, en Sechura de enlatados y congelados para el consumo nacional e internacional. En Piura se procesa el algodón, por parte de la Textil Piura, y se fabrica aceite de semilla de algodón. Además a partir del petróleo, en Talara se produce fertilizantes.

\section{4. 3. El sector terciario: los servicios y el comercio}

Un factor importante de diferenciación que influye tanto sobre la producción agro-ganadera como sobre el nivel de organización socioeconómica, política y cultural, es la infraestructura vial. Las redes viales tienen un desarrollo desigual de un lado y otro de la frontera.

En los años 70, en Ecuador, los militares modernizan y extienden una densa red vial, que sigue bastante bien mantenida. Carreteras asfaltadas o afirmadas permiten circular con vehículos motorizados por todos los cantones durante todo el año.

En Perú, no existe una red vial de calidad y densidad comparable a la ecuatoriana. En la costa es menos densa y en la sierra se constata la carencia de carreteras asfaltadas por lo que permanece hasta ahora muy aislada. Si las capitales de provincia, Ayabaca y Huancabamba, están conectadas de manera casi permanente a Piura, la capital del departamento, por medio de carreteras afirmadas, no hay paso vehicular directo entre estas dos ciudades. La circulación entre Piura y las capitales de distrito, Frías, Santo Domingo, Chalaco y Pacaipampa, es todavía bastante aleatoria durante la estación de lluvias, y sólo se circula entre estos pueblos en vehículos motorizados durante la estación seca, por algunas trochas mejoradas. Se sigue transitando en la sierra piurana en acémilas y a pie, por antiguos caminos de herradura.

En cuanto a los servicios que se brindan a través de infraestructuras productivas y sociales, no sólo la red vial sino también los sistemas de electrificación, de agua potable, así como de atención de salud y educación son más desarrollados en Ecuador que en Perú, aunque se han detectado carencias y espacios poco o nada servidos. Se puede afirmar, entonces, que debido a sus condiciones de aislamiento, la población de la sierra piurana es menos integrada al mercado nacional que la población de la sierra lojana y su producción se orienta más hacia el mercado regional y el autoconsumo.

En cuanto al comercio, en los dos países esta en manos de intermediarios que concentran la producción, principalmente agropecuaria, adquiriéndola directamente de los productores. Por otro lado, los dueños de almacenes y de tiendas, así como un 
conjunto importante de arrieros y vendedores ambulantes, aseguran la distribución de todo género de artículos tanto en los centros urbanos como en el campo.

La ruta marítima sigue siendo la principal ruta comercial entre los dos países, su importancia rebasa el ámbito regional. En Ecuador el comercio marítimo pasa por el puerto multi-servicios de Guayaquil y por el bananero de Puerto Bolívar. En Perú pasa por el puerto multi-servicios de Paita, por el puerto petrolero de Bayovar, terminal del oleoducto que viene de la Amazonia, y por el puerto petrolero de Talara, donde se procesa, almacena y comercializa el petróleo producido en esta zona, cuya explotación está actualmente en crisis.

\section{4. 4. Las actividades ilícitas y clandestinas}

No se puede dejar de lado dos importantes actividades, difíciles de evaluar porque son ilícitas y clandestinas: el contrabando y el tráfico de drogas. Es un secreto a voces que el ganado, la gasolina y el gas ecuatoriano pasan la frontera en cantidades considerables a nivel local. Se sabe también que desde los años 60-70 la coca y desde hace sólo algunos años atrás, la amapola y la marihuana, bajo una forma u otra de transformación, entran en Ecuador. Los ingresos que se obtienen por este tráfico de drogas, sin duda, contribuyen al desarrollo regional, un impacto que se traduce en un cierto mejoramiento de la arquitectura domestica urbana, si bien en un discutible estilo "gringo nuevo rico" y, en casos puntuales, en el medio rural. Y son estas actividades de contrabando y paso de droga las que justificarían el mantenimiento de un control militar además de los controles fronterizos, policiales y aduaneros.

Con esta idea general de la extrema complejidad del contexto regional, para percibir las transformaciones inducidas por los acuerdos de paz a escala local, releamos los cuadernos de notas tomadas en marzo 2001 cuando visitamos, viniendo de Quito con dos colegas geógrafos Pierre Gondard y Freddy López, los tres nuevos pasos fronterizos.

\section{UNA VISIÓN LOCAL DE LA REALIDAD}

\section{1. El paso Lalamor-Alamor}

\section{1. 1. El entorno}

El paso Lalamor-Alamor, a unos $100 \mathrm{~m}$ de altitud, se ubica entre las dos márgenes del río Alamor, justo antes de su confluencia con el río Chira que desemboca en el océano Pacífico. Se sitúa en una ecorregión de bosque seco, una formación de algarrobal, con charanes en las lomas, que a partir de unos $500 \mathrm{~m}$ se transforma en ceibal.

Del lado ecuatoriano la producción es ante todo ganadera; caprinos y bovinos se desplazan entre las dos formaciones del bosque seco. En las quebradas, parcelas cercadas producen cultivos intensivos de decreciente como arroz, cebollas, tomates y maíz duro.

Del lado peruano se maneja ganado caprino en el algarrobal y, en menor cantidad que en Ecuador, vacuno en el ceibal. La producción agrícola se concentra en las quebradas, en particular la de Venados-Jaguey Negro que tiene más agua y donde se practica una agricultura de decreciente, que puede alcanzar tres cosechas en los mejores años. Se 
cultivan cebollas y tomates, para la venta, camote, maíz y arroz para el consumo familiar. En años lluviosos se siembra, en las chacras cercadas de las vertientes de los cerros Amotape, maíz criollo blando, con el prehispánico palo sembrador de guayacán.

\section{1. 2. Las vías de comunicación}

Del lado ecuatoriano, la carretera baja de Celica, a 2000 m de altitud, por Pózul y Pindal hasta Zapotillo, población ubicada en la margen derecha del río Chira que marca la frontera. Esta carretera se está asfaltando en el tramo Celica-Pindal y ya lo está entre Pindal y Zapotillo. Más allá de Zapotillo, para llegar a Lalamor, hay un camino de unos $25 \mathrm{~km}$ en muy malas condiciones, afectado por las fuertes lluvias que caen entre enero y abril, estación húmeda durante la cual este tramo es, a veces, intransitable. Zapotillo y Lancones son dos cabeceras administrativas de pocos recursos locales, la primera cantonal y la segunda distrital.

Del lado peruano, una carretera afirmada viene desde Sullana, por la margen derecha del río Piura, a lo largo de la represa de Poechos, hasta Lancones. Desde allí, cruzando la quebrada de Venados, sigue unos $30 \mathrm{~km}$ hasta llegar a Alamor, población peruana que no debe confundirse con la ciudad ecuatoriana de Alamor. Esta carretera fue destruida por las lluvias torrenciales que cayeron a raíz de los eventos El Niño de 1983 y del 1997 y nunca fue rehabilitada. No queda ningún puente y el tráfico se interrumpe durante la estación de lluvias frente a la quebrada de Venados.

Los Programas Nacionales Peruano y Ecuatoriano de Construcción y Mejoramiento de la Infraestructura Productiva en las Regiones Fronterizas "B”, del lado ecuatoriano, prespuestan, en cuanto a caminos rurales, un monto de 600000 US \$ para carreteras en el cantón Zapotillo, sin precisar donde se invertirán. Así mismo, preven 70900000 US \$ para los puentes, sin proporcionar otra precisión. Del lado peruano preven 3200000 US \$, para el tramo El Alamor-Lancones sin indicar kilometraje.

No hay puente para atravesar el río Alamor, los vehículos y las personas lo cruzan por un vado en estación seca y el tránsito se interrumpe con las crecidas de la estación húmeda. No hay tampoco infraestructura alguna que facilite los intercambios: los productos se depositan sobre los cantos rodados, la tierra o en el lodo y el trasbordo de las mercancías lo realizan cargadores.

Del lado ecuatoriano, sólo se observan algunas casas, mientras que del lado peruano hay un pequeño caserío, más consolidado. En ambos lados de la frontera no se encuentran facilidades de alojamiento y alimentación en condiciones mínimas de salubridad. En las dos márgenes del río se ubican sendos puestos de control fronterizo y se mantienen los puestos de control militar localizados uno entre Zapotillo y Lalamor y otro en Lancones.

Como se dijo anteriormente, los Programas Nacionales Peruano y Ecuatoriano de Construcción y Mejoramiento de la Infraestructura Productiva en las Regiones Fronterizas “B”, preven la construcción de Centros Nacionales de Atención Fronteriza CENAF. Para la construcción de 4 CENAF, en Aguas Verdes-Huaquillas, AlamorLalamor, La Tina-Macará y Namballe-Zumba, el Ecuador estima un costo de infraestructura de 1450000 US \$ y un costo de equipamiento de 3300000 US \$, o sea 
un total de 4750000 US \$. El Perú estima un costo de infraestructura de 1380000 US \$ y un costo de equipamiento de 3120000 US \$, es decir un total de 4500000 US \$. Para los 4 CENAF, en los dos países, se estima un costo total de 2830000 US \$ en infraestructura y 6420000 US \$ para equipamiento, lo que arroja un total de 9250000 US \$. Es de notar que en este acápite desaparece el paso CariamangaAyabaca.

\section{1. 3. El tránsito fronterizo}

En el paso Lalamor-Alamor desde siempre transitan productos entre Perú y Ecuador y la creación de este paso fronterizo no es más que la oficialización de los flujos locales. Muchos productos entran también por la cabecera cantonal ecuatoriana de Zapotillo que no fue elegida como paso oficial. Los productos que van hacia Ecuador son, principalmente, maíz duro costeño peruano, cuando se agota la producción de la zona de Pindal, y tomates y cebollas que provienen de la quebrada de Venados. Hacia el Perú pasa el contrabando de gasolina y gas ecuatoriano y, según las circunstancias, algo de ganado vacuno.

La frontera entre el río Chira y la quebrada de Cazaderos en los cerros Amotape es una zona de contrabando de ganado vacuno. El ganado puede provenir no sólo de las provincias sureñas sino también desde Pichincha, Santo Domingo de los Colorados, y Esmeraldas. Se transporta en camiones por el eje de la costa del Ecuador y por la carretera a Zapotillo o la de Alamor y El Limo, baja, a pie, por los bosques secos, se echa al río, se recoge en la banda peruana y se conduce hasta la carretera, para ser, finalmente, transportado en camiones hasta Sullana. Se debe subrayar que actualmente este tráfico está disminuyendo como consecuencia del alza de los costos debido a la dolarización decretada en Ecuador. También se debe notar que el control sanitario de los animales es totalmente insuficiente.

\section{1. 4. Los cambios inducidos por los Acuerdos de Paz}

El impacto esperado como resultante de la habilitación del paso Lalamor-Alamor se deja ver en los cantones fronterizos de Zapotillo, Pindal y Celica, en forma de obras de infraestructura de agua potable y alcantarillado sanitario que son anunciadas en grandes vallas y paneles del Fondo Binacional.

Los presupuestos para estas obras son de 135 mil US \$ en Celica y Pózul, para agua potable 35 mil US \$ van para Pózul donde se rehabilitó la red de agua potable, que había sido destruida por el Niño de 1998, así como su extensión, de 200 a 250 usuarios. Pero el contrato, firmado por el anterior alcalde sin adecuados estudios preliminares y sin licitación, no incluyó el reservorio desarenador, el cercado de la captación y el sistema de válvulas que permite la sectorización de la red de distribución. Además, este proyecto consideró una sola de las dos redes de abastecimiento de la parroquia y no tomó en cuenta a dos barrios, sembrando la discordia entre la población. Otros carteles anuncian 65000 US \$ en Pindal, donde la municipalidad realiza un estudio del relleno sanitario por 3500 US \$ y un estudio del alcantarillado pluvial por 8000 US \$ y 38715 
US \$ en Zapotillo para el sistema de alcantarillado sanitario de la parroquia Garza Real. La municipalidad de Zapotillo también amplia el alcantarillado sanitario de la ciudad por 180424 US \$.

Estos fondos corresponden a la parte ecuatoriana de los Programas Nacionales Peruano y Ecuatoriano de Construcción y Mejoramiento de la Infraestructura Social y de Aspectos Ambientales en las Regiones Fronterizas "C", que presupuestan 41383500 US \$, para el lado ecuatoriano, de los cuales se destinarán 25 millones para agua potable, 14 millones para alcantarillado y 2283500 US \$ para letrinas. Del lado peruano, están previstos 20773440 US \$ para agua potable, 21383280 US \$ para alcantarillado y 8628420 US \$ para letrinas, lo que da un total de 50785140 US \$. Es de notar que Zapotillo y Alamor, junto con Macará, Amaluza y Cariamanga comparten 300000 US \$ destinados al tratamiento de los desechos sólidos que provienen de la USAID y que administra CARE. Es de recalcar que los fondos de US-AID se destinan casi exclusivamente a agua potable, letrinas o alcantarillado.

En octubre 2000, se suscribió un convenio para la ejecución del Proyecto Binacional de Desarrollo de Servicios de Saneamiento Básico Rural, con 600000 US \$ de aporte suizo no reembolsable, a ser ejecutado en ambos países por CARE en las zonas de Zapotillo-Ecuador y Lancones-Perú.

\section{2. El paso Cariamanga-Ayabaca}

\section{2. 1. El entorno}

El paso Cariamanga-Ayabaca, a $2000 \mathrm{~m}$ de altitud, es por ahora el puente internacional sobre el río Espíndola, en la parte alta de la cuenca del río Chira. Cariamanga, en Ecuador, dista de Ayabaca, en Perú, unos $200 \mathrm{~km}$ y a medio camino entre estas dos ciudades se pasa por la de Amaluza, localizada a unos $30 \mathrm{~km}$ antes de llegar al puente. Este paso se sitúa en la ecorregión de selva alta, quedan algunos relictos de bosque en las quebradas y se observan grandes espacios cubiertos con bosques de neblina localizados por arriba del espacio cultivado.

La producción ganadera es para el consumo local, con algo más de bovinos del lado ecuatoriano, en particular en las haciendas, con una parte de la producción orientada hacia la leche, mientras que hay más ovinos del lado peruano. En ambos lados de la frontera se crían porcinos. En la sierra lojana, si bien el control sanitario podría ser más eficiente, hay veterinarios. En cambio en la sierra piurana no hay control y son escasos los veterinarios.

La producción agrícola varía en función de los pisos altitudinales. Del lado ecuatoriano domina el maíz duro, para las fábricas de alimentos balanceados, seguido por el café, cultivo que dibuja una franja en forma de cinturón en la vertiente interior de la cordillera oriental. Del lado peruano, se siembra para el consumo maíz criollo blando, poco café y, en las alturas, papas y ocas. De ambos lados de la frontera, en los valles bajos, calientes y más secos, con el maíz se cultiva conjuntamente maní y yuca. 


\section{2. 2. Las vías de comunicación}

Del lado ecuatoriano, la carretera afirmada baja de Cariamanga, situada a una altitud de 1500 m, hasta el río Pindo, a unos 1000 m, y sube a Amaluza, a una altitud de unos $1700 \mathrm{~m}$. De Amaluza se vuelve a subir hasta Jimbura, ubicada a unos $2200 \mathrm{~m}$ de altura, para llegar a la divisora de aguas entre el valle de Jimbura y la cuenca alta del Calvas, a $2300 \mathrm{~m}$, desde donde se baja hasta llegar al puente internacional. Es una carretera que a veces se interrumpe durante la estación húmeda.

Del lado peruano, las conexiones se realizan por un camino de herradura mejorado, que se habilita en camino carrozable durante la estación seca. Este camino viene desde Ayabaca, a unos $2700 \mathrm{~m}$ de altura, baja hacia Socchabamba, a unos $2100 \mathrm{~m}$ y pasa por El Molino, a 1300 m, para subir nuevamente hasta Espíndola.

El itinerario entre Cariamanga y Ayabaca, las dos ciudades que identifican este paso, es mucho más largo en kilómetros y tiempo que el tramo entre Zapotillo y Lancones porque sigue un trazado más accidentado. Además, Cariamanga, Amaluza y Ayabaca, en orden de importancia, son, a escala serrana, grandes capitales de cantones, en Ecuador y de provincia, en Perú, mientras que Zapotillo y Lancones son pequeñas cabeceras de cantón y de distrito, a escala costeña.

Del lado ecuatoriano, junto al puente, existe un pequeño puesto de control fronterizo de madera del mismo estilo que las casuchas donde se alojan e intercambian algunas familias. Del lado peruano, a unos pocos metros del puente, se construyó en mampostería un nuevo puesto de control fronterizo. En los dos lados existen controles militares, el del lado ecuatoriano se ubica a la salida de Jimbura y el peruano en Espíndola.

Se debe subrayar que si bien en el artículo 14 del Acuerdo Amplio de 1998 se considera el paso de frontera Cariamanga-Ayabaca en el Programa Binacional de Proyectos de Infraestructura Social y Productiva “A”, en su rubro de Interconexión Vial, se han identificado cinco ejes viales prioritarios entre los cuales no figura el eje Cariamanga-Ayabaca. Sólo se menciona:

- Guayaquil-Machala-huaquillas-Aguas Verdes-Tumbes Piura, eje 1.

- Arenillas-Pindal-Zapotillo-Lalamor-Alamor-Lancones-Sullana, eje 2.

- Loja-Catacocha-Macará-La Tina-Sullana, eje 3.

- Loja-Vilcabamba-Zumba-Chinchipe-Namballe-Jaén-Bagua-Santa María de Nieva- Saramiriza, eje 4.

- Mendez-Yaupi-Borja-Saramiriza (Campaquiz-Santiago), eje 5.

En cuanto a los Programas Nacionales Peruano y Ecuatoriano de Construcción y Mejoramiento de la Infraestructura Productiva en las Regiones Fronterizas "B", no prevén obviamente la construcción de un CENAF en el puente Espíndola.

Los avances del Plan Binacional a diciembre 2000 señalan que se están realizando los estudios de factibilidad del Eje Vial 1, Guayaquil-Piura, del Eje Vial 2, Arenillas-Sullana, del Eje Vial 3, Loja-Sullana, delEje Vial 4, Loja-Saramiriza y delEje 5, Mendez-Santa María de Nieva. Pero no consideran un eje serrano que pasa de Cariamanga a Amaluza y Ayabaca. Los documentos oficiales, elaborados desde Quito 
y Lima, o más allá, descartaron un eje que fue abierto por los alcaldes fronterizos en tiempos de guerra y que representa un esfuerzo municipal para hermanar pueblos fronterizos a pesar de políticas nacionales de conflictos armados.

Surge una pregunta que se puede formular en los siguientes términos: ¿Esta omisión se relaciona con la ignorancia de quienes redactan los textos oficiales sin considerar la realidad local y regional o con la dificultad de fijar definitivamente el lugar del paso entre las dos ciudades, dado que Amaluza compite con Cariamanga como ciudad fronteriza? De hecho hay que reconocer que sería más corto y más rápido ir de Cariamanga a Ayabaca por el itinerario del camino de herradura que pasa por Vado Grande-El Remolino, siguiendo un eje norte-sur directo, pero se dejaría de lado Amaluza.

El paso por el puente de Espíndola se beneficia de la infraestructura vial existente, si bien es precaria de los dos lados de la frontera, y resulta de una visión de ordenamiento del territorio que supieron desarrollar las municipalidades de Amaluza y Ayabaca. Esta misma visión de integración del espacio se manifiesta en el empeño del alcalde de Amaluza para terminar, del lado ecuatoriano, la construcción de la carretera AmaluzaZumba que probablemente será inaugurada a fines de 2001.

Es de destacar que la visión de los alcaldes que construyeron el puente Espíndola, en cuanto al desarrollo del sistema de comunicación vial, se funda en la recuperación de la histórica red de caminos que integraba de las sierras lojana y piurana desde tiempos preincaicos. Una red de caminos de herradura que se mantiene durante el Incanato, la Colonia y la República hasta la guerra del 41. Existen huellas del gran camino que de Cusco a Quito pasaba por Huancabamba a Cariamanga, vía Aypate, la Ayabaca incaica situada muy al este del asentamiento español, y por Espíndola, donde la estrechez del río entre los acantilados permitía tender un puente colgante. El camino seguía por Jimbura hacía Cariamanga y de él se desprendían ramales hacia la costa y la Amazonia. Uno de ellos se dirigía a Palanda y Zumba a partir de Jimbura.

Hay que notar que el nuevo alcalde de Ayabaca, con menos responsabilidad que su antecesor y con otros compromisos políticos, no da mucha continuidad a los proyectos que no elaboró él mismo, no mantiene como debería el camino a Amaluza y quiere abrir una ruta hacia Cariamanga por Vado Grande, otro paso tradicional.

\section{2. 3. El tránsito fronterizo}

El tránsito actual de productos perpetúa los antiguos flujos impuestos por la proximidad de los espacios a los que actualmente se añade la novedad de los tallarines, del aceite vegetal procesado y la mantequilla vegetal que entran al Perú, junto con la gasolina y el gas. En el otro sentido, el maíz criollo blando, entra al Ecuador junto con las cobijas "Tigre", de fabricación industrial. El ganado criollo, vacas y toros, junto con porcinos, pasa de un lado al otro de la frontera, en una dirección u otra, según unos períodos de intercambio difíciles de prever ya que dependen de las condiciones locales de la producción y de los mercados tanto locales como nacionales. Los domingos una feria libre se instala alrededor del puente donde se realizan los intercambios locales. 
La zona fronteriza entre Cariamanga y Ayabaca ha sido siempre, y continúa siendo, una zona de contrabando de animales y de abigeato. Los negociantes de ganado compran los vacunos ya sea en Ecuador o en Perú, dependiendo de las condiciones del mercado, y "al paso arriman a la manada" algunos animales robados a lo largo del camino. Atraviesan en uno u otro sentido por los vados del río Espíndola-Calvas.

Es de notar que en esta zona de la frontera existe, también, una conocida ruta de tráfico de drogas que viene de Jaén y se transita en mula o a pie en dirección a Cariamanga.

\section{2. 4. Los cambios inducidos por los Acuerdos de Paz}

Como en el caso de Lalamor-Alamor, el impacto de la habilitación del paso, se percibe a lo largo de la carretera en forma de paneles que anuncian las obras del Plan Binacional, ejecutadas por CARE con recursos del Fondo binacional aportados por el gobierno de Estados Unidos US-AID.

En el puente del río Pindo, se observa el primer cartel del cantón Espíndola, que anuncia un proyecto de unidades sanitarias integrales para la comunidad del centro cívico de la Ramada, con un costo de 5280 US \$, trabajo realizado en asociación con otra ONG, Espacios Saludables. Luego, otro cartel en Tambo Airo anuncia un proyecto de agua potable para las comunidades de La Huaca, El Laurel, El Batán, El Guabo y El Tambo, con un costo de 72000 US \$ pagado con fondos de la misma fuente y la participación del Concejo Provincial de Loja. En Las Lajas, existe un proyecto de unidades sanitarias integrales que tiene un costo de 7200 US \$. En Las Limas se comunica un proyecto similar, con un costo de 5400 US \$. Finalmente, en Amaluza existe un proyecto de manejo de desechos sólidos que tiene un costo de 40000 US \$, parte de los 300 mil US \$ destinados al tratamiento de los desechos sólidos que comparte Amaluza con Cariamanga, Macará, Zapotillo y Alamor. Además, la municipalidad de Espíndola gracias al Fondo Binacional ha adoquinado las vías urbanas de Amaluza, con una asignación de 100 mil US \$.

Estos proyectos corresponden a la parte ecuatoriana de los Programas Nacionales Peruano y Ecuatoriano de Construcción y Mejoramiento de la Infraestructura Social y de Aspectos Ambientales en las Regiones Fronterizas “C”.

Se debe precisar que estos proyectos, en cuanto a agua potable se limitan a la construcción de reservorios y de redes de tuberías y en cuanto a "Unidades Sanitarias Integrales", se refieren en realidad a la construcción de letrinas, una de las cuales se observó con detenimiento en Las Limas. Son construcciones de unos $3 \mathrm{~m}^{2}$, con muros de ladrillo y techo de 2 planchas de Eternit. Disponen de un reservorio de agua, cuyo abastecimiento depende del buen funcionamiento de la red de agua potable. La evacuación va hacia un pozo de tierra que no dispone de ningún tipo de adecuación y que se inunda en la estación de lluvias, quedando rápidamente fuera de uso. Además, en este proyecto los beneficiados, que en el Airo fueron 120 familias según el alcalde de Amaluza, debieron aportar unos 20 US \$ y mano de obra, y en algunos casos, como el visitado, las letrinas no se terminaron de construir. Como rezan sus afiches "donde está CARE hay esperanzas". 


\section{3. El paso Zumba-Namballe}

\section{3. 1. El entorno}

El paso Zumba-Namballe, a unos $750 \mathrm{~m}$ de altitud, atraviesa el río Canchis en La Balsa. Aguas abajo este río forma, con el río Mayo, el río Chinchipe cuyas aguas corren al Marañón. Se sitúa en una zona de transición de selva alta a bosque seco. En la selva alta en las alturas de las cordilleras se conservan extensos bosques de neblina, con podocarpus, localizados más arriba de las zonas cultivadas. En las quebradas quedan algunos relictos de bosque a manera de galería.

Toda esta zona de la vertiente oriental de los Andes se encuentra bajo influencia amazónica. La sequedad local de los fondos de valles, marcada con nitidez por la presencia de ceibos en el valle inferior del río Chinchipe, en territorio peruano, se debe al encajonamiento de esta área entre la Cordillera de los Andes, al oeste y la cordillera del Cóndor y su prolongacación, al este.

La producción ganadera es principalmente de vacunos criados en pastizales cultivados. La producción agrícola es, sobre todo, de maíz duro, junto con caña y yuca. En esta zona, desde San Ignacio en Perú, hasta más allá de Zumba la principal fuente de recursos económicos es el café.

\section{3. 2. Las vías de comunicación}

Del lado ecuatoriano un camino carrozable, pero en muy mal estado, baja de Zumba, a 1350 m, por El Tablón, El Chorro y Pucapamba y recorre una distancia de unos $30 \mathrm{~km}$ hasta La Balsa. Del lado peruano, un camino afirmado viene de Namballe, a $850 \mathrm{~m}$ de altitud y recorre una distancia de unos $10 \mathrm{~km}$ hasta La Balsa. Para pasar el río Canchis no hay puente, sino una gabarra o balsa cautiva, que atraviesa el río amarrada a un cable tendido entre las dos márgenes.

Del lado ecuatoriano hay un puesto de control fronterizo nuevo y desde el año 2000 se van construyendo unas casuchas de madera en un sitio muy estrecho de la terraza fluvial. Del lado peruano hay un puesto de control fronterizo en La Balsa, un caserío antiguo de algunas decenas de casas a lo largo de la carretera que sigue a Carmen de la Frontera, provincia de Huancabamba.

De los dos lados hay puestos de control militar, antes de Pucapampa en Ecuador y en La Balsa y Namballe en Perú. La construcción de un CENAF está previsto en el marco de los Programas Nacionales Peruano y Ecuatoriano de Construcción y Mejoramiento de la Infraestructura Productiva en las Regiones Fronterizas “B”.

\section{3. 3. El tránsito fronterizo}

El tránsito de productos, ante todo ilícitos, entre los dos países siempre fue una realidad en este paso, como en otros a lo largo de la frontera. La carretera afirmada que viene de Jaén por Namballe permite llegar a La Balsa. Después de la habilitación del paso, en el año 2000, del lado ecuatoriano se abre el camino que permite la circulación de vehículos entre Pucapamba y La Balsa. Camiones, camionetas, buses y chivas, llegan 
hasta la orilla del río. El trasbordo de las mercancías es realizado por cargadores y se atraviesa el río en una balsa cautiva.

Salen del Perú, sacos de maíz duro, arroz, cebollas, papas, pescado (caballas saladas), bultos de ropa, cajones enteros de aparatos de radio japoneses y de artesanías de madera de zapote elaborados en Catacaos. Todos estos productos provienen de la costa, por Chiclayo o Piura y Jaén, salvo el arroz que también puede llegar de los valles de la vertiente amazónica. Salen del Ecuador, tallarines, aceite y margarina vegetales, atún enlatado y, a la vista de todos como contrabando, gasolina y gas, 3 y 4 veces más baratos que en Perú, respectivamente.

En cuanto al contrabando de animales, entran actualmente al Ecuador algunos ejemplares bovinos mejorados que vienen de Jaén y, es bastante obvio que deben entrar también, pasta básica de cocaína y látex de amapola que transitan por esta provincia peruana hacia otros destinos.

\section{3. 4. Los cambios inducidos por los Acuerdos de Paz}

El impacto de la habilitación del paso no se señala con paneles a lo largo de la carretera, como en los dos otros nuevos pasos fronterizos, pero se deja sentir con fuerza, en el mercado dominical de Zumba. El Fondo Binacional ha dado 265000 US \$ para que los municipios de Zumba y Catamayo construyan sus mercados. Entorno al mercado de Zumba unos 15 vendedores sobre 40 feriantes son peruanos que pasan por La Balsa a partir del sábado en la tarde para negociar sus productos el domingo. Los vendedores ecuatorianos ofrecen la producción local además de los productos agro-alimenticios que transitan y arriban desde Loja. Sin embargo, algunos de ellos venden productos peruanos como cebollas, papas y caballa salada, que compran en Loja a peruanos que pasan esta mercancía por Aguas Verdes-Huaquillas o por La Tina-Macará. Este último era el itinerario normal del comercio antes de la habilitación del paso y de la construcción del camino Pucapamba-La Balsa. Ahora el nuevo itinerario pasa más al sur a partir de Chiclayo y Piura, utilizando los grandes ejes asfaltados, y prosiguiendo por Jaén, San Ignacio, Namballe y La Balsa, hasta llegar a Zumba.

Es de recalcar que si se asfaltaría en su totalidad la carretera Jaén-La BalsaZumba-Loja y se construiría un puente sobre el río Canchis, de los tres nuevos pasos fronterizos, este sería el que mayor interés presentaría para las conexiones amazónicas, como contrapunto del paso costero en Aguas Verdes-Huaquillas. De hecho se ubica sobre un nuevo eje vial, en la vertiente amazónica de la cordillera de los Andes, eje que nos parece vital para el desarrollo y la integración de la región fronteriza. Y parece que las autoridades locales, nacionales e internacionales están de acuerdo. En septiembre 2001 se firman los acuerdos que permiten iniciar la construcción del puente internacional de la Balsa, con financiamiento del Fondo Binacional y aporte del gobierno de Brasil.

Para resumir la situación fronteriza, por más coyuntural que sea esta anécdota que no deja de ser reveladora de las dificultades materiales de una integración regional, vale señalar que en marzo 2001 no logramos cruzar la frontera en vehículo en ninguno de los tres nuevos pasos. El río Alamor estaba crecido en Lalamor-Alamor, el camino había sido interrumpido por un derrumbe justo antes del puente Espíndola, y en La Balsa pocos son los vehículos que se arriesgan llegar hasta el río, menos a pasarlo en balsa. 
Conversamos, del lado ecuatoriano en marzo 2001, con los fronterizos y sus representantes electos así como con diversos actores externos, para tratar de percibir las opiniones de la población local respecto a los cambios inducidos por los acuerdos de paz. Contrastamos estas opiniones con las de los peruanos, con quienes no dejamos de debatir desde 1986 de la condición fronteriza y que volvimos a entrevistar en mayo de 2001, con el sociólogo Étienne Durt y el ingeniero Vidal Pino. Retornemos entonces a nuestros cuadernos de apuntes.

\section{5. ¿INTEGRACIÓN Y DESARROLLO DE LA REGIÓN FRONTERIZA?}

\section{1. La percepción de los cambios}

El sentimiento compartido y expresado por todos los ecuatorianos en la zona fronteriza refleja un gran alivio frente a las tensiones e inquietudes que eran las suyas antes de la firma de los acuerdos de paz. Todos dicen que: “ila paz quién no la quiere?", "estamos más tranquilos, no hay temor", se puede "vivir sin zozobra para empeñarse en su trabajo". De hecho, en Ecuador existía un real temor a la confrontación armada con Perú, a raíz de lo ocurrido en 1941. En el cantón Zapotillo "se recuerda que los peruanos quemaron el pueblo y que los habitantes migraron por el miedo de la guerra". Del otro lado de la frontera, todos los peruanos tienen el mismo sentimiento de tranquilidad, de alivio, pero no expresan con tanta nitidez que los ecuatorianos el temor frente a la guerra, quizás porque en el conflicto del 41 ellos fueron los invasores y aterrorizaron a sus vecinos del Norte.

Hoy, "el espíritu de hermandad existe", "la firma de la paz, es como quitar un dique para que las relaciones fluyan de nuevo" y esto se siente en los dos lados de la frontera. Pero, "si hay paz, si no hay miedo, las trabas al comercio son idénticas como antes". Las frases siguientes, recogidas en las entrevistas, pueden ilustrar de mejor manera las trabas a las que se hace referencia. "Con los acuerdos de paz, los militares debían retirarse a $20 \mathrm{~km}$ de la frontera... pasó mucha gente, pero después de seis meses los militares, un poco celosos de ver tanta gente que entraba, empezaron a rumorear que hay contrabando y que hacen falta los controles... que pasa la gasolina, que vuelve el abigeato. Y rebuscan a los peruanos. Los militares siguen con el prejuicio, abusan, en el control decomisan". Del otro lado de la frontera las quejas son las mismas, todos coinciden en que no deja de haber corrupción y soborno, si bien reconocen que en ambos países no todos los que controlan actúan de la misma forma. Y nadie sabe cuáles son los 584 productos de libre circulación entre los dos países.

Ecuatorianos y peruanos admiten que la frontera nunca fue un obstáculo a los intercambios. Cuentan los campesinos de Amaluza, que "después de la guerra del 95 se había cerrado la frontera y los contactos se hacían de noche. Ahora, después de la paz, se puede pasar abiertamente de día", "los productos pasaban antes, lo que cambió es el ambiente, el paso es tranquilo". "Esto sí, hay más peruanos que vienen que ecuatorianos que van", y en estas afirmaciones se percibe algo de resentimiento del lado ecuatoriano. Se dice que "el negociado de la paz dejó la zona desabastecida, el ganado se fue y los precios subieron", "los toretes y vacas gordas se fueron, aquí pelamos los animales flacos", "se llevan lo mejor a los vecinos" y "llevando el ganado juntan otros, vuelve el 
abigeo". En Celica se cuenta que "antes del 41 venían los peruanos con recuas de mulas, hoy vienen de nuevo como ambulantes", "desde la paz hay más peruanos que vienen a vender, traen ropa, medicina, yerbas, plásticos", "los vendedores ambulantes vienen del Perú, ninguno sale del Ecuador", "vienen los curanderos a vender medicinas, no van los ecuatorianos a las Huaringas de Huancabamba, es demasiado caro". Y las quejas son algo amargas, de hecho la situación económica dificulta el tránsito y el negocio de los ecuatorianos. Los ganaderos del cantón Celica se quejan de la "mucha corrupción, el Perú no da permiso, por más que tengamos los papeles como se deben, los policías o los militares no dejan pasar o decomisan el ganado y lo dejan en cuarentena sin darle agua o forraje, vendemos a Loja y a Guayaquil... Cuenca está saturada por el ganado del oriente".

De ambos lados de la frontera, la población y sus autoridades electas reclaman una parte de los “3 mil millones de US \$” que corresponden a las estimaciones de los costos de los cuatro programas del Plan Binacional y que fueron anunciados por la prensa como un incentivo recibido cuando se firmaron los acuerdos de paz. Pero pocos conocen los textos de los acuerdos de paz o saben lo que es CARE.

Hablando de las obras realizadas del lado ecuatoriano, y recordando que se ha invertido 10 millones de US \$ a través de la sola ventanilla de "Financiamiento de proyectos de infraestructura social, productiva, ambiental y de servicios", hay quejas. La población está de acuerdo con que se instale agua potable y letrinas, reconoce que se necesita saneamiento ambiental, pero todos esperan más. Muchos constatan fallas en la realización de estas obras y critican, sean los alcaldes, sean las ONGs que las gestionan y ejecutan. $\mathrm{Y}$ es cierto, CARE, que administra los fondos de US-AID destinados a la frontera en los dos países, tiene imposición de dedicar la primera remesa a proyectos de saneamientos, agua potable, alcantarillado, rellenos sanitarios y letrinas. De hecho muchos municipios reclaman participación en la toma de decisiones sobre el uso de los fondos de la paz y en la realización de los proyectos de desarrollo.

Del lado peruano la población señala que las obras ejecutadas en el marco de los acuerdos de paz dependen de instituciones ajenas al municipio, que tienen un impacto local muy limitado. No olvidemos que la inversión es menos de la mitad de la ecuatoriana, que los proyectos se financian a través de las tres ventanillas, de "Preparación de proyectos para la promoción de la inversión privada y estudios especiales", de "Financiamiento de proyectos de infraestructura social, productiva, ambiental y de servicios" y de "Proyectos de participación ciudadana y desarrollo comunitario". Hasta fines de 2000 se dispersan sin lógica de desarrollo planificado, sino de propaganda gubernamental. Las obras realizadas tienden a facilitar la difusión de imágenes y discursos a favor de la perpetuación de un gobierno mafioso, a ganar votos a favor de autoridades corruptas, sembrando algo de cemento y calamina. Las obras son antenas de televisión y redes eléctricas, son muros y techos de aulas escolares o postas medicas, donde no hay quién enseñe o cure, como se debería, son pequeños sistemas de agua potable o alcantarillado en beneficio de individuos o familias.

Los alcaldes ecuatorianos, por su parte, se sienten forzados a elaborar proyectos en función de las ventanillas del Plan Binacional. No rechazan recursos que permiten mejorar los servicios de agua potable, letrinas, alcantarillado, rellenos sanitarios, 
adoquinado de vías urbanas y otros, pero saben que sin proyectos productivos no cambiarán realmente las condiciones de vida de sus administrados. Requieren primero más programas de educación y capacitación y segundo más proyectos de carreteras asfaltadas, sistemas de riego y otras infraestructuras de producción y comercialización, sin olvidar el sueño de todos, el establecimiento de circuitos turísticos. Los alcaldes peruanos se quejan con justa razón de no recibir fondos.

Vimos que de hecho algunas de estas autoridades locales elaboraron proyectos que involucraron municipalidades de un lado y de otro de la frontera y que no esperaron la firma de los acuerdos de paz y la contribución globalizada para emprender la restauración y consolidación de las relaciones transfronterizas. Realizaron obras con recursos propios, restablecieron flujos existentes desde hace mucho tiempo atrás, fortaleciendo antiguos lazos de parentesco como fue el caso entre Amaluza y Ayabaca, cuando los dos alcaldes congeniaban. Pero cambió el alcalde de Ayabaca y las relaciones son otras. De hecho el nuevo alcalde de Ayabaca se entiende con el de Cariamanga favoreciendo la idea de establecer el paso fronterizo entre estas dos ciudades. En Amaluza y Zapotillo las municipalidades demostraron tener también sus propios proyectos de infraestructura productiva, "pero no nos financian las ONGs", "sólo quieren proyectos de salud y saneamiento, no quieren entrar en otros... está mal, quizás hay que tener paciencia y quizás entenderán, habrá algo mejor... ¿por qué las ventanillas del Fondo Binacional no nos permiten entrar en proyectos de educación o de producción?". Los alcaldes piensan que la realización de proyectos que no son percibidos como prioritarios por la población, desaniman y aumentan el "que-meimportismo de la gente".

Resumiendo nuestras impresiones, del lado ecuatoriano, a pesar de un cierto y comprensible descontento de la población y de sus representantes, se nota algo de mejoría en las condiciones de vida, en base a un desarrollo de las infraestructuras básicas locales con los recursos asignados por el Fondo Binacional y gestionados bajo la responsabilidad de las autoridades municipales y algunas ONGs, si bien condicionados por la ventanilla de "Financiamiento de proyectos de infraestructura social, productiva, ambiental y de servicios", escogida por el gobierno ecuatoriano. Mientras que del lado peruano los cambios inducidos por los acuerdos de paz son menos visibles a nivel local, es de notar que no hay paneles que los anuncian. Los proyectos de desarrollo fronterizo no son responsabilidad de los municipios, sino de los CTARs y de algunas ONGs, Caritas, CARE, CIPCA y se invierte más en reuniones y estudios que en realizaciones. Volveremos sobre el tema en un siguiente artículo, por ahora basta subrayar que de una parte y de otra de la frontera, en los tres pasos fronterizos que visitamos, lo que se nota es un desarrollo desigual que aumenta el desnivel de las condiciones de vida entre los fronterizos ecuatorianos y peruanos (Hocquenghem \& Durt, por publicar).

Lo que constatamos, por ahora y desde el punto de vista de los tres nuevos pasos fronterizos, es que a pesar de las intenciones y las ejecutorias realizadas, dos años y medio después de la firma de los acuerdos de paz, no se notan muchos cambios a lo largo de la frontera. Los fronterizos, cada cual por su lado, siguen viviendo entre esperanzas $\mathrm{y}$ frustraciones, con una conciencia local, pero no regional. 


\section{2. La No-Región fronteriza}

Tratamos de indicar que los textos firmados por los gobiernos de Perú y Ecuador en Brasilia el 26 de octubre de 1998 no toman en cuenta la realidad local y no se refieren a la integración de una región fronteriza y a su desarrollo. Los acuerdos y convenios tratan de imponer las reglas de juego que permiten, reconociendo la frontera entre Perú y Ecuador, anularla en la perspectiva de una integración binacional al mercado mundial, según los esquemas neoliberales que definen el actual proceso de globalización. El objetivo es unificar a escalas locales, regionales y nacionales los dos países para dominarlos mejor. Intentamos también de percibir, a nivel local, el impacto de estos acuerdos sobre la integración y el desarrollo de los pueblos fronterizos y constatamos que hay una notable inadecuación entre los objetivos del discurso oficial y los resultados de los programas implementados para lograrlos.

El Acuerdo Amplio Peruano-Ecuatoriano de Integración Fronteriza, Desarrollo y Vecindad pretende restablecer la confianza y la comunicación entre las poblaciones locales, mejorar las condiciones de tránsito, facilitar los intercambios entre los países vecinos, incentivar la producción, igualando el nivel material de vida de las poblaciones fronterizas para unificarlas. Pero los proyectos que se vienen ejecutando, en el marco de los dos Programas Nacionales Peruano y Ecuatoriano, "B" y "C" del Plan Binacional, al no tomar en cuenta las especificidades locales, no conducen a la unificación de los pueblos fronterizos, si no al contrario, realizados en dos contextos políticos diferentes, profundizan las fracturas y las diferencias transfronterizas, conduciendo a un desarrollo material desigual de parte y de otra de la frontera.

Sabemos que no será solamente el impacto local de pequeños proyectos elaborados y ejecutados en forma independiente, de uno y otro lado de la frontera, que permitirá la integración de la región fronteriza. Esta depende de una articulación entre las provincias ecuatorianas y los departamentos peruanos que podría conformarse a partir del Programa Binacional de Proyectos de Infraestructura Social y Productiva “A”. Pero este programa se refiere a grandes proyectos ya previstos en la década del 70 , que deberían ser reconsiderados, abandonados o redefinidos, en el actual contexto político, socioeconómico, legal y ambiental. Hasta ahora no se llevan a cabo, por lo tanto no tienen impactos. Y es lo mismo en cuanto a los proyectos previstos en el Programa de Promoción de Inversión Privada “D”, apuntan a una integración binacional, demostrando con claridad en qué medida los sectores públicos están dejando la posta a los sectores privados para liderar el proceso de globalización. Pero por ahora no se perfilan inversiones privadas en la región fronteriza.

En realidad, a nivel local, poco importa una integración binacional y en cuanto a una integración regional, la mayoría de los fronterizos no la vislumbra más allá de sus estrechas perspectivas e intereses específicos, tranquilidad, libre paso de personas y productos de ambos lados de la frontera para acceder a los mercados locales y regionales, para reunirse entre familiares. Son pocas las autoridades electas, los líderes políticos, los profesores o promotores que piensan, por encima de la gestión de sus bienes personales, en una gestión conjunta de recursos naturales o culturales por compartir, sea entre vecinos de un mismo lado o de otro lado de la frontera. Todos anhelan un desarrollo local material y social que pocos idean, y quienes elaboran 
proyectos a partir de lo que realmente perciben como necesidades básicas, tomando en cuenta los problemas y las posibilidades del entorno, reconocen que tienen pocas esperanzas de llevarlos a cabo, lo que los conduce a aceptar sin mucha discusión los proyectos que se ofrecen y financian desde el exterior, o a migrar en busca de mejores condiciones de vida.

Es obvio que nos quedan por observar los impactos de la globalización a nivel regional, considerando el tránsito en los dos principales ejes transfronterizos, PiuraAguas Verdes-Huaquillas-Machala y Piura-La Tina-Macará-Loja. Esto sin olvidar que la mayor parte de los productos que transitan entre Ecuador y Perú circulan por la vía marítima entre los puertos de Guayaquil y del Callao, y que los que salen de, o entran en, la región fronteriza lo hacen por los puertos de Machala y Paita. Además debemos precisar la naturaleza de los intercambios terrestres y de los circuitos comerciales transfronterizos, sus fluctuaciones anuales y las condiciones del mercado o de las tasas arancelarias y de cambio que varían según la situación socioeconómica y política de los dos países. También debemos considerar el conjunto de los planes de desarrollo y de los proyectos realizados a nivel regional, sea por el sector público, sea por el sector privado, para apreciar los avances y el impacto de los programas del Plan Binacional. Lo haremos, tratando de vislumbrar si en el marco del actual proceso de globalización la región fronteriza se divisa como un territorio ganador o perdedor.

Rechazando la idea de que los esquemas neoliberales son ineluctables y considerando que una de las características de la región fronteriza es su abundancia de recursos naturales y culturales, seguimos pensando que es una "región posible", que podría constituir un territorio ganador, no en el contexto del actual proceso de globalización, pero en el contexto de un proceso histórico abierto. Esto a condición de que se conforme una sociedad regional capaz de enfrentar la realidad de sus problemas y posibilidades de integración y de desarrollo, fortaleciendo la conciencia de su identidad, sin perder de vista sus interrelaciones con las sociedades que la engloban a nivel nacional, internacional y mundial. Por ahora constatamos que esta condición no está dada, la globalización se extiende según los esquemas neoliberales y los fronterizos, quienes a nivel local e individual no conciben la región, no tienen la capacidad de participar en la elaboración de planes de integración y desarrollo regional, menos en el diseño de nuevas políticas de reproducción social.

Surge entonces una primera serie de preguntas, a las cuales intentaremos responder en otro artículo (Durt, 2001b; Hocquenghem \& Durt, por publicar): ¿A nivel regional e institucional, cuáles son las organizaciones encargadas de idear la región?, ¿en estas instituciones, cuáles son los actores que intentan concebirla?, ¿desde qué puntos de vista, qué perspectivas, qué títulos, y con qué instrumentos la imaginan?, ¿cómo comparan, comparten y compatibilizan las diversas imágenes que proyectan?, ¿cómo se adecuan estas proyecciones a la realidad?, ¿cómo influye el proceso de globalización en la concepción de estas imágenes? y ¿cómo elaborar escenarios alternativos en el marco de un proceso histórico abierto?

Se anuncia además otra serie de interrogantes: ¿Cómo relacionar los discursos y las realidades que se elaboran y perciben a diversas escalas, local, regional, nacional, internacional y global?, ¿cuáles son las especificidades de la región fronteriza ecuatoriano- 
peruana y de su historia, frente a otras regiones fronterizas andinas?, ¿cuál es el sentido actual de los límites internacionales en Sudamérica, entre otros en el marco del Acuerdo de Libre Comercio de las Américas, ALCA, y más allá, en la perspectiva del actual proceso de globalización?

\section{Referencias citadas}

ADOUM, J. E., 1997 - Ecuador: señas particulares, 209p.; Quito: Esheletra.

ALTAMIRANO, T., 1992 - Éxodo. Peruanos en el exterior, 224p.; Lima: Pontificia Universidad Católica del Perú.

APEL, K., 1996 - De la hacienda a la comunidad: la sierra de Piura 1934-1990, 281p.; Lima: CNRS-IFEA-IEP.

BALBI, C., 1997 - Le Fujimorisme : délégation sous surveillance et citoyenneté. Problèmes d'Amérique Latine, $\mathbf{N}^{\circ}$ 25: 30-58; Paris: La Documentation Française.

BALBI, C., 2000 - Pérou: l'élection présidentielle de 2000 et l'impossible maintien au pouvoir d'un régime autoritaire. Problèmes d'Amérique Latine, $\mathbf{N}^{\circ}$ 38: 5-28; Paris: La Documentation Française.

BARRERA, M., GASTELLU, J.-M., HOCQUENGHEM, A.M. \& TUEROS, R., 1993 - Le travail des femmes à Frías: modèle andin et variante régionale. Bulletin de l'Institut Français d'Études Andines, 22 (3): 739-761; Lima.

BOISIER, S., 1992 - El difícil arte de hacer región, 216p.; Cusco: Centro Bartolomé de las Casas.

BONILLA, A., 1999 - Ecuador-Perú. Horizontes de la negociación y al conflicto, 380p.; Quito: Adrían Bonilla editor, FLACSO Ecuador.

BOURLIAUD, J., DOLLFUS, O. \& GONDARD, P., 1998 - Pérou, Le Haut Huallaga, de la coca à l'abandon. Problèmes d'Amérique Latine, $\mathbf{N}^{\mathbf{0}}$ 28: 109-123; Paris: La Documentation Française

BOURDIEU, P., 2001 - Contre-feux 2, 108p.; Paris: Editions Raisons d'Agir.

BURGOS, D., 2000 - Villa el Salvador: un bilan de la participation politique. Problèmes d'Amérique Latine, $\mathbf{N}^{\circ}$ 38: 101-116; Paris: La Documentation Française.

BRACK, A., 1986a - Las eco-regiones del Perú. Boletín de Lima, $\mathbf{N}^{\circ}$ 44: 57-70; Lima.

BRACK, A., 1986b - Ecología de un país complejo. In: Gran Geografía del Perú. Naturaleza y Hombre, Vol. II: 177-31; Lima: Manfer-Juan Mejía Baca.

CARRANZA, V., 2000 - Globalización y crisis social en el Perú, 155p.; Lima: IFEAUniversidad Ricardo Palma.

COMBLIN, J., 1977 - Le pouvoir militaire en Amérique latine. L'idéologie de la sécurité nationale, 229p.; Paris: Jean-Pierre Delarge.

CORDES-Gobernabilidad, 1999 - La ruta de la gobernabilidad. Informe final del Proyecto "CORDES-Gobernabilidad", 583p.; Quito: Fernando Pachano ed.

CUVI, P., 1999 - Al filo de la Paz. Historias de la negociación con Perú, 241p.; Quito: Dinediciones.

DAMMERT EGO AGUIRRE, M., 1992 - El Perú: Tarea Pendiente. Bases para un proyecto nacional descentralista, 101p.; Lima: CENEAP.

DAMMERT EGO AGUIRRE, M. (ed.), 1993 - Perú desafío democrático, 269p.; Lima: La República. 
DAMMERT EGO AGUIRRE, M., 1996 - La dictadura imagocrática y la afirmación democrática de la ética en la política. Politik, $4^{\circ}$ cuadrimestre: 20-26; Lima: Fundación Hanns Seidel, Foro Democrático.

DAMMERT EGO AGUIRRE, M., 1999 - Desborde territorial descentralista. Replanteando la reforma descentralista peruana. Territorios sociales, Estado con regiones y municipios, impulso autonómico, 213p.; Lima: Tarea, Asociación Gráfica Educativa.

DAMMERT EGO AGUIRRE, M., 2001a - La democracia territorial. Hacia la refundación nacional descentralista, 194p.; Lima: Tarea, Asociación Gráfica Educativa.

DAMMERT EGO AGUIRRE, M., 2001b - El Estado Mafioso, 404p.; Lima: Ediciones El Virrey.

DELER, J.-P., 1981 - Genèse de l'espace équatorien. Essai sur le territoire et la formation de l'État national, 277p.; Lima - Paris: Institut Français d'Etudes Andines - éditions ADPF.

DELER, J.-P., 1987 - Ecuador: del espacio al Estado nacional, 341p.; Quito: Banco Central del Ecuador. Biblioteca de Geografía Ecuatoriana, 2.

DELER, J.-P., 1991 - Structures de l'espace entre Loja et Piura: continuités, transitions et différenciation transfrontalière. Bulletin de l'Institut Français d'Etudes Andines, 20(2): 279-294, Lima. $N^{\circ}$ spécial: Piura et sa région (Anne Marie Hocquenghem ed.)

DELER, J.-P., 1992 - El área amazónica: litigios y conflictos, In: Nueva historia del Ecuador, Volumen 12, Ensayos generales I: espacio, población, región (Ayala Mora, Enrique ed.) 340-350; Quito: Corporación Editora Nacional-Grijalbo Ecuatoriana (Nueva Historia del Ecuador, 12).

DELER, J.-P., 1995 - Recurrence guerrière dans la Cordillère du Condor: Les enjeux matériels et symboliques du conflit frontalier entre l'Équateur et le Pérou. Revue Internationale de Politique Comparée, Vol 2, no 3: 519-531.

DE RIVERO, O., 1998 - El mito del desarrollo. Los países inviables en el siglo XXI, 266 p.; Lima: Fondo de Cultura económica.

DOLLFUS, O., 1997a - La mondialisation, 166p.; Paris: Presses de Science Po.

DOLLFUS, O., 1997b - La prise d'otages de Lima: symboles, tragédie et politique. Problèmes d'Amérique Latine, $\mathbf{N}^{\circ}$ 25: 59-64; Paris: La Documentation Française.

DOLLFUS, O. \& BOURLIAUD, J., 1997 - L'agriculture de la côte Péruvienne au vent du néoliberalisme. Problèmes d'Amérique Latine, $\mathbf{N}^{\circ} 25$ : 87-104; Paris: La Documentation Française.

DONOSO PAREJA, M., 1998 - Ecuador: identidad o esquizofrenia, 197p.; Quito: Esheletra.

DURT, É., 2001a - Descentralizar: Hasta dónde y con quién? Actualidad Económica del Perú, No 214, Año XXIV: 21-24; Lima.

DURT, É., 2001b - Paz y amistad al extremo norte del Perú. ¿Ser o no ser una región fronteriza? Actualidad Económica del Perú, $\mathbf{N}^{\circ}$ 220, Año XXIV: 32-35; Lima.

ETECÉ, 2002 - Gente del bosque. Etecé, $\mathbf{N}^{\circ} \mathbf{8 1}, 1$ de febrero de 2002; Lima.

FRANCO, C., 2000 - Les relations des États-Unis avec l'Amérique latine: "le cas péruvien". Problèmes d'Amérique Latine, $\mathbf{N}^{\circ}$ 38: 29-50; Paris: La Documentation Française.

GASTELLU, J.-M., 1994 - Una respuesta al Fujishock: las invitaciones con pago en Lima. Bulletin de l'Institut Français d'Études Andines, 23(2): 297-315, Lima.

GLEICH, A. von, 1996 - La corrupción: mal social y desprestigio de la política. Politik, $4^{\circ}$ cuadrimestre: 37-39; Lima: Fundación Hanns Seidel, Foro Democrático.

GONDARD, P., 1983a - Ritmos pluviométricos y contrastes climáticos en la provincia de Loja. Cultura: Revista del Banco Central del Ecuador, Vol. 15 N$^{\circ}$ 5: 39-58; Quito: Edición monográfica dedicada a la provincia de Loja.

GONDARD, P., 1983b - La utilización del suelo y los paisajes vegetales en la provincia de Loja. Aproximación a los sistemas de producción agrícolas. Cultura: Revista del Banco Central del Ecuador, Vol. 15 N 5: 285-329; Quito: Edición monográfica dedicada a la provincia de Loja. 
GONDARD, P., 1983c - Interrogantes en torno a la región sur. Cultura: Revista del Banco Central del Ecuador, Vol. $15 \mathbf{N}^{\circ}$ 5: 343-350; Quito: Edición monográfica dedicada a la provincia de Loja.

GONDARD, P. \& MAZUREK, H., 2001 - 30 años de Reforma agraria y colonización en El Ecuador (1964-1994): Dinámicas espaciales. In: dinámicas territoriales, Estudios de geografía, volumen 1: 15-40; Quito: IRD, CEN, PUCE.

GONZÁLES DE OLARTE, E., 1997 - Pérou: le blocage des réformes économiques nóliberales. Problèmes d'Amérique Latine, $\mathbf{N}^{\circ}$ 25: 65-85; Paris: La Documentation Française.

GONZÁLES DE OLARTE, E., 2000 - Neocentralismo y neoliberalismo en el Perú, 123p: Lima; Instituto de Estudios Peruanos.

GUZMÁN, M. A., 1996 - Pobreza, Modernización del Estado y Privatización en Ecuador, 305p.; Cuenca: Universidad del Azuay - Deutsche Gesellschaft für Technische Zusammenarbeit.

HERRERA, J., 2000 - Ajustement et mobilité économique à Lima. Problèmes d'Amérique Latine, $\mathbf{N}^{\circ}$ 38: 71-99; Paris: La Documentation Française.

HOCQUENGHEM, A. M., 1990 - Cambios en el sistema de producción de la sierra piurana, siglos XV y XVI. Bulletin de l'Institut Français d'Études Andines, 19(1): 87-101; Lima.

HOCQUENGHEM, A. M., 1991 - Frontera entre "áreas culturales" nor y centroandinas en los valles y la costa del extremo norte peruano. Bulletin de l'Institut Français d'Études Andines, 20(2): 309-348; Lima. $\mathrm{N}^{\circ}$ spécial: "Piura et sa région" (Anne Marie Hocquenghem, ed.).

HOCQUENGHEM, A. M., 1998 - Para vencer la muerte. Piura y Tumbes: raíces en el bosque seco y en la selva alta - Horizontes en el Pacífico y en la Amazonia, 445p.; Lima: IFEAINCAH-CNRS.

HOCQUENGHEM, A. M., 2001 (en prensa) - La Universidad y el desarrollo de una región fronteriza, multicultural y binacional : un proyecto de creación de institutos de estudios regionales, Piura Comunidad: Tierra-Hombre-Identidad. Revista del centro de investigación y promoción cultural Raíces, Piura.

HOCQUENGHEM, A. M. \& DAMMERT EGO AGUIRRE, M., 1999 - Un proyecto de escuela ambiental en el extremo norte del Perú, Bulletin de l'Institut Français d'Études Andines, 28(3): 461-466; Lima.

HOCQUENGHEM, A. M. \& DURT, É., (por publicar) - Entre las instituciones y los actores: una visión regional. Bulletin de l'Institut Français d'Études Andines, Lima.

HOCQUENGHEM, A. M. \& LANNING, Z., 1996 - El Instituto Francés de Estudios Andinos: 48 años de investigaciones en ciencias del hombre y la naturaleza en el extremo norte del Perú. In: Encuentro Internacional de Peruanistas: Estado de los estudios históricosociales sobre el Perú a fines del siglo XX, 3-6 septiembre, Lima: Universidad de Lima.

HOCQUENGHEM, A. M. \& LANNING, Z., con la colaboración de GONDARD, P., 1999 Contribución al conocimiento de una zona de encuentros entre los Andes ecuatorianos y peruanos, 76p.; Lima: CNRS-IFEA-IRD.

HOCQUENGHEM, A. M. \& LUHMANN, V. , 1988 - La agricultura en la zona del Alto Quiroz, Piura, Piura: Informe CIPCA.

HUBER, L., 1995 - "Después de Dios está la ronda”. Las rondas campesinas de Piura, 132p.; Lima: IFEA-IEP-CNRS.

HURTADO, O., 1997[1977] - El poder político en el Ecuador, 417p.; Quito: Planeta.

HUTTEL, C., ZEBROWSKI, C. \& GONDARD, P., 1999 - Paisajes agrarios del Ecuador, 285p.; Anexos, 1 mapa escala 1/1000.000. Quito: IRD-IPGH-IFEA-IGM- PUCE,

JIMÉNEZ, F., 2000 - Stabilisation et ajustement économique au Pérou: Les limites du modèle néoliberal. Problèmes d'Amérique Latine, $\mathbf{N}^{\circ}$ 38: 51-70; Paris: La Documentation Française.

LEGOFF, J., 2001 - Heurs et malheurs des mondialisations. Le Monde, 17 Novembre 2001; Paris. 
MERCADO JARRÍN, E., 1981 - El conflicto con Ecuador, 155p.; Lima: Ediciones Rikchay Perú.

MESCLIER, É., 1997 - Pérou: analyse des dynamiques sociales et cartographie. Problèmes d'Amérique Latine, $\mathbf{N}^{\circ}$ 25: 105-129; Paris: La Documentation Française.

MESCLIER, É., 2000 - Trente ans après la reforme agraire péruvienne : le discours des investisseurs contre la voie paysanne. Problèmes d'Amérique Latine, $\mathbf{N}^{\circ} 38$ : 117-141; Paris: La Documentation Française.

MESSNER, D., 2000 - Desafios de la globalización, 315p; Lima: Friedrich Ebert Stiftung.

MINISTERIO DE RELACIONES EXTERIORES DEL PERÚ, 1998 - Acuerdos Suscritos Entre El Perú y El Ecuador en Brasilia, El 26 De Octubre de 1998, 201p.; Lima.

NEIRA, H., 1996 - Hacia la tercera mitad. Perú XVI-XX, 754p.; Lima: Fondo editorial SIDEA.

OTÁROLA, A., 1996 - Democracia y corrupción en el Perú: apuntes para una redefinición del problema. Politik, 5-19; Lima: Fundación Hanns Seidel, Foro Democrático.

PACHANO, S., 1998 - La representación caótica. Análisis del sistema electoral ecuatoriano, 108p.; Quito: FLACSO Ecuador, Konrad Adenauer Stiftung.

PLAN BINACIONAL, 2001 - Plan Binacional de Desarrollo de la Región Fronteriza, EcuadorPerú a diciembre del 2000, Capítulo Ecuatoriano, Quito. Ms.

PLAN BINACIONAL, 2001 - La sociedad fronteriza peruano-ecuatoriana y el plan binacional de desarrollo, Capítulo Peruano, 161p.; Lima.

PLANAS, P., 1998 - La descentralización en el Perú republicano (1821-1998), 588p.; Lima: Municipalidad de Lima.

SÁNCHEZ PARGA, J., 1999 - La modernización y el Estado. Fin del ciclo del Estado-nación, 255p.; Quito: CELA-PUCE-ABYA-YALA.

TAMAYO, E., 2001 - Ecuador: Protestas tres un año de dolarización. Actualidad Económica del Perú, $\mathbf{N}^{\circ}$ 214, año XXIV: 20-22; Lima.

TOURAINE, A., 1997 - Pourrons-nous vivre ensemble? Égaux et différents, 395p.; Paris: Fayard.

ULLOA, A., 1997[1964] - Perú y Ecuador. Última etapa del problema de límites. 1941-1942, 123p.; Lima: Fondo editorial del Ministerio de Relaciones Exteriores del Perú, Fondo editorial del Banco Central de Reserva del Perú.

VARGAS HAYA, H., 1996 - Corrupción y democracia. Politik, 4º cuadrimestre; 27-36; Lima: Fundación Hanns Seidel, Foro Democrático.

YEPES, E., 1996 - Un testimonio inédito del Departamento de Estado: El informe McBride. Mito y Realidad Perú-Ecuador, 1942-1949, 253p.; Lima: Ediciones Análisis.

YEPES, E., 1998 - Perú Ecuador 1941-1942. Trás días de guerra, ciento ochenta de negociaciones, 426p.; Lima: Universidad Nacional Agraria La Molina, Universidad del Pacifíco.

ZAS FRIZ BURGA, J., 1998 - La descentralización ficticia: Perú 1821-1998, 350p.; Lima: Centro de investigación de la Universidad del Pacífico.

ZAS FRIZ BURGA, J., 2001 - El Sueño Obcecado. La descentralización política en América andina, 561p.; Lima: Fondo Editorial del Congreso de la República. 